\title{
African Land Ecology: Opportunities and Constraints for Agricultural Development
}

\author{
R.L. Voortman, B.G.J.S. Sonneveld, and M.A. Keyzer \\ CID Working Paper No. 37 \\ January 2000
}




\title{
African Land Ecology: opportunities and constraints for Agricultural development
}

\author{
R. L. Voortman, B. G. J. S. Sonneveld, and M. A. Keyzer
}

\begin{abstract}
Current agriculture in Sub-Sahara Africa is undeveloped and the Green Revolution has left the continent largely untouched. Poor performance is often related to a number of socio-economic factors. In this paper we argue that there are also some specifities of natural resources, namely local homogeneity and spatial diversity of the pre-dominant Basement Complex soils, that imply that simple fertilizer strategies may not produce the yield increases obtained elsewhere.
\end{abstract}

Keywords: Sub-Sahara Africa, Agro-Ecology, Land use, Land resources, Basement Complex, Green Revolution, Micronutrients, Fertilizer Policy

JEL Classification: N57, O33, Q15

An earlier version of this paper was presented at the Workshop on "Explaining African Economic Growth Performance," held at Harvard University, March 26-27, 1999. The workshop was sponsored by the African Economic Research Consortium and the Weatherhead Center for International Affairs.

R. L. Voortman is a land resource ecologist specializing in agro-ecological characterization and assessment for agricultural development planning with emphasis on climate-vegetation-soil chemistry relationships.

B. G. J. S. Sonneveld is an agronomist/soil scientist specializing in land development and land degradation with particular emphasis on water erosion modelling.

M. A. Keyzer is Professor of mathematical economics and methods of applied economic research. 
CID Working Paper no. 37

Explaining African Economic Growth Performance Conference Series

\title{
African Land Ecology: opportunities and constraints for agricultural development $\mathrm{t}^{12}$
}

\author{
R. L. Voortman, B. G. J. S. Sonneveld and M. A. Keyzer
}

Tropical ecosystems are extremely complex. Lack of adequate information about the nature of these ecosystems has bred many myths relating to the agricultural potential of the ecosystems and about the function offertilizers in crop production (Mokwunye and Hammond, 1992).

\section{Introduction}

In most of (Sub-Saharan) Africa crop yields and the use of external inputs in agriculture are much lower than in other developing countries. Over the last three decades, average per caput food supplies remained more or less stagnant, at somewhat less than $2200 \mathrm{kcal}$ per caput per day. Between 1980 and 1990 per caput agricultural production even declined or stagnated and in only eight countries a modest growth could be recorded. Food availability has by now dropped below the UN minimum standard and continues to fall on average In addition, while the percentage of the population that is undernourished decreased rather sharply in most other parts of the world, it showed in Africa a slow but steady increase to over forty percent in the early nineties. (Alexandratos, 1996; FAO, 1996; IFPRI, 1996).

At the same time, the African population grows at more than three percent per annum, well above the rest of the developing world, and this implies that a four percent annual increase of agricultural production is required over the next thirty years, if demand for food and fiber is to be met (World Bank, 1989, 1996b; Cleaver 1993). Such increases are to be achieved through yield improvement, more intensive use of land currently in cultivation and expansion of the cultivated area. This is not an easy task. Yield improvement and more intensive use of land can only be sustained if external inputs are applied, and area expansion is difficult since currently unused land is mostly of lower productivity or more susceptible to land degradation. In fact, arable land per caput has been decreasing in Africa $(\mathrm{FAO}, 1996)$ and the more frequent use of the same piece of land without increasing external input use

\footnotetext{
${ }^{1}$ The research for this paper was sponsored by the A frican Economic Research Consortium (AERC), N airobi. The paper was presented at the workshop Explaining African Economic Growth Performance organized by AERC and the Weatherhead Centre for International Affairs, 26-27 M arch, Harvard University, USA.

${ }^{2}$ The authors thank M arcel Fafchamps, K upukile M lambo and Charles Soludo for their comments as discussant.

${ }^{3}$ The authors are associated with the Centre for W orld Food Studies at the V rije U niversiteit, A msterdam (A cronym: SOW-VU) as land resource ecologist, agronomist/soil scientist and economist/director, respectively.
} 
has resulted in widespread land degradation through the effects of nutrient mining and erosion (Stoorvogel et al., 1993).

While the Green Revolution has been responsible for important production increases elsewhere, it has largely left the African continent untouched. Green Revolution technology requires using high yielding crop varieties, with reliable water supply, in combination with macro-nutrient fertilizer applications to which these varieties are responsive (Nitrogen, Phosphorus and Potassium, NPK for short). In South and East Asia such technologies have been responsible for about ninety percent of the increase in production over the past three decades, while only ten percent is attributable to area expansion (Reuler and Prins, 1993). In Africa, during the late eighties, the area planted to modern varieties stood at a mere 3 percent and on average only $11 \mathrm{~kg}$ of fertilizer was used per hectare, as compared to 30 per cent and $63 \mathrm{~kg}$, respectively, on average in other less developed countries (Alexandratos, 1995). Past growth of agricultural output was mainly based on area expansion and during the nineties the consumption of mineral fertilizer increased only at a 0.6 percent annual rate, starting from very low levels, while the growth rate in other developing regions was 4.4 percent on average (FAO, 1996). Consequently, crop yields per hectare have remained at low levels.

The non-adoption of Green Revolution technology in Africa has in the past been attributed to a large number of factors, mostly of a socio-economic nature. Clearly, many African farmers are faced with tight cash constraints and limited access to credit. The price ratios between food crops and fertilizers tend to be unfavourable and the timely availability of fertilizer is not assured. More generally, local markets for inputs as well as outputs have many imperfections. In addition, low population densities and large distances create less favourable conditions and consumer goods are often lacking in rural areas, reducing the incentive to produce beyond local needs. It is also frequently mentioned that the institutional frameworks for agricultural research and extension are weakly developed (Eswaran et al., 1992; Quiñones et al., 1997, Sanchez et al., 1992) and that farmers consequently lack access to technologies that are in principle available.

These institutional factors undoubtedly play an important role in explaining the poor growth performance of agriculture in Africa and yet they only tell part of the story. In situations where the application of macro-nutrients could raise the yields significantly, farmers have shown an impressive ability to adopt new technology, organizing themselves at short notice to secure the appropriate type of inputs at the right time (Mokwunye and Hammond, 1992). Similarly, at a broader, national scale, production increases in Zimbabwe, that went hand in hand with increased fertilizer use, confirm that poor farmers with little education can be fast adopters of technologies, provided these suit their needs and conditions (Dudal and Roy, 1993). At the same time, these successes raise some doubts as to the appropriateness of the commonly recommended technology packages in situations where farmers seem more reluctant. Indeed, there is now ample evidence that the mere application of macro-nutrient fertilizer may not lead in Africa to yield increases comparable to those in Asia (e.g. APMEU, 1987; 
Heisey and Mwangy, 1996). It is increasingly recognized that the nutrient requirements for soil improvement are in Africa as diverse as they are in temperate zones and that fertilizer recommendations need to become more site-specific (Eswaran et al. 1992; Dudal, 1998; Buresh et al., 1997). Moreover, even in Asia the yields from Green Revolution varieties have started declining, partly because the micro-nutrients reserve in the soil has been depleted, and this also calls for more site-specific recommendations (e.g. Tandon, 1995).

In short, it might well be that the reluctance of African farmers to adopt new practices is not a cause of the current problems, but only an expression of the inappropriateness of the technology that is being offered, because the natural conditions in Africa are truly different from those in the countries where the Green Revolution was successful initially. In this case it will be necessary to develop new technological alternatives.

This paper reviews the evidence on this issue. Rather than engaging in detailed analysis of the natural conditions in a particular region, it chooses a broad perspective that tries to convey to nonagriculturists that agricultural growth cannot be achieved on a sustainable basis in Africa unless some specificities of climatic conditions and soils are duly accounted for. The paper proceeds as follows. Point of departure is the spatial distribution of population in Africa (section 2). As farmers live on the land they cultivate, this distribution gives a first indication of site selection and land use intensity, and can be related to agroclimatic conditions and crop choice. It appears that farmers mostly select areas where the climate is reliable, and where the climate is unreliable they choose varieties with low but assured yields (section 3). Next, we look into crop and site selection from the perspective of geology and soil conditions, comparing Asia and Africa. The most notable difference is the prevalence in Africa of soils derived from a particular geological formation (i.c. metamorphic Basement Complex rock), whereas in Asia the successes of the Green Revolution were largely achieved on alluvial and volcanic soils (section 4). It appears, not surprisingly, that the most suitable soils are being cultivated already but that there is significant scope for output growth, especially if the appropriate fertilizers are applied to redress chemical imbalances in both the currently cultivated and the uncultivated soils (section 5). In addition, climate related output variability could be reduced through irrigation (section 6). Yet such growth is not sustainable if land degradation is allowed to persist. In this respect water erosion seems to pose the main problem, especially if cropping practices are intensified and cultivation is expanded into marginal areas (section 7). Section 8 concludes. 


\section{Population density}

Since our investigation proceeds from the basic premise that population and land use densities reflect resource potentials, it is natural to choose the population density map of Africa as the point of departure. Figure 1 (source: Deichmann, 1997; unit: number of inhabitants per square $\mathrm{km}$ ) shows that the dry zones of the Sahara and Kalahari are almost unoccupied, and that the dryer areas of Somalia, Kenya, Southern Mozambique and South Africa are sparsely populated. High population

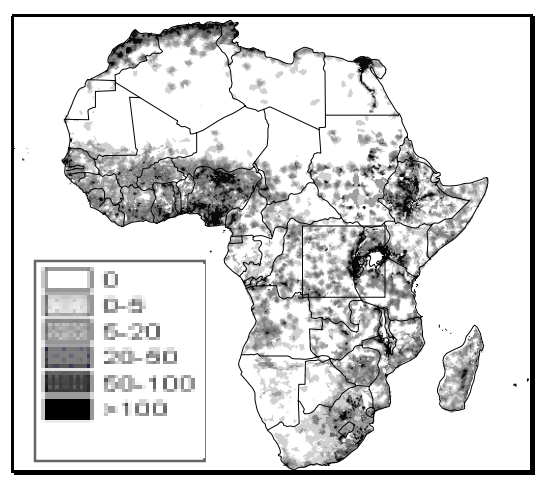

Figure 1. Population density $\left(\mathrm{p} / \mathrm{km}^{2}\right)$ densities are found in Nigeria, and under highland conditions in Ethiopia, East Africa, Angola and South Africa. Population densities are generally higher in West Africa. Elsewhere, the picture is characterized by local concentrations. This patchy pattern is especially pronounced in the rainforest zone of the Congo basin.

To highlight this, Figure 2 zooms in on the rectangle box in Figure 1 that includes Lake Victoria and the string of Rift Valley lakes, and extends to the west into this rainforest zone. To the east, we notice the higher population densities in the highlands around Lake Victoria, where the climate is not as humid as in the rainforest area and where soils are generally more fertile. Within this area, very high population densities occur in Rwanda, Burundi and Uganda on favourable agricultural soils that are derived from volcanic materials or contain enrichments of volcanic ashes. To

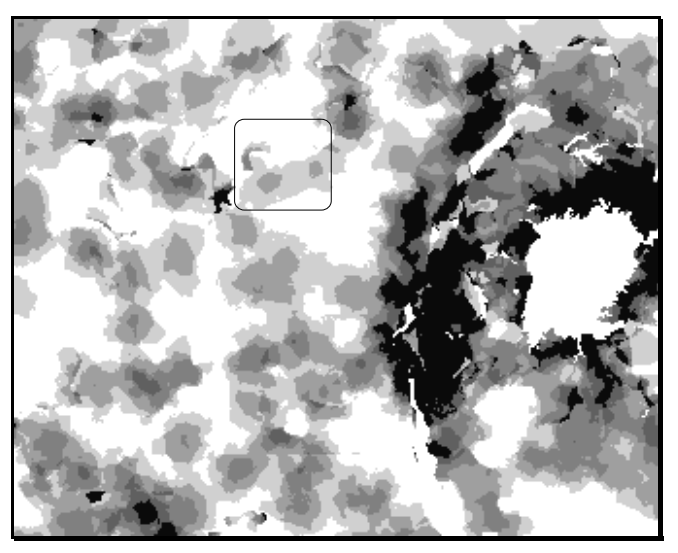

Figure 2. Zooming in on Lake Victoria the west, in the humid lowlands, we can recognize the patchy pattern. Population densities are very low on the typical poor and leached soils of the rainforest zone, and somewhat higher on the patches with soils of better quality.

For example, consider the small box inside Figure 2. The three nuclei represent settlement areas of approximately $10000 \mathrm{~km}^{2}$ and are situated on Basement Complex rock. For each of them one could engage in elaborate research to chart out the historical events and socio-economic factors that affected their creation and development. However, it is unlikely that this would offer any explanation as to why the areas around them are uninhabited. Given the size of the nuclei and the subsistence nature of the agricultural operations in this part of the continent, the nuclei can hardly be expected to result from any urbanization process or more generally from scale economies of any sort. While there might be, within every nucleus, some concentration of population in villages and along roads, the figure does 
not capture these details. It rather refers, at a higher scale, to farmers performing shifting cultivation on vast expanses.

Then, the question of interest is why these farmers stay clear of certain areas. In line with common notions in landscape ecology (see Troll, 1950; Vink, 1975; Zonneveld, 1995), we speculate that this is largely caused by unfavourable climatological and soil conditions, arguing that the population would be spread in a less clustered manner if these conditions were the same throughout the area. This hypothesis obviously rests on simplification and needs further empirical testing but we nonetheless choose it as our frame of reference for this paper because it conforms remarkably well to the evidence that will be presented on land use patterns in relation to climate and soil conditions.

\section{Agro-climatic conditions and land use}

The agro-climatic conditions will be described in terms of the constraints they impose on crop selection and land use. Our discussion refers mainly to rainfed production circumstances because of their large potentials for improvement at relatively low costs. The possibilities for irrigation will be discussed in a separate section (section 6).

To describe the agro-climatic conditions, we follow FAO's Agro-Ecological Zones (AEZ; FAO, 1998) approach and distinguish four key variables: temperature, the average length of the growing period (LGP), i.e. the period during which sufficient moisture is available for a crop to grow, the LGPvariability between years and the LGP-pattern i.e. the sequence of rainy seasons within a year and the incidence of interruptions (dry spells) within a rainy season.

\section{Temperature}

The first step of an AEZ-assessment is to make an inventory of temperature data. This is followed by spatial interpolation, resulting in maps, and their evaluation with respect to the requirements of crops. It appears that temperature does not pose any constraint for crop production in Africa. It can be too low on isolated mountain peaks and too high under desertic conditions but elsewhere on the continent the prevailing temperatures are suitable for crop production. Nonetheless, the temperatures during the growing period to a large extent determine which crops can be grown profitably. In most of Africa, temperatures are well suited for a broad range of tropical crops, though the highlands are only suited for temperate crops or varieties. Temperate crops are usually found above 1000-1500 meters altitude, depending on latitude and the period of the year when moisture is available for crop growth. At medium altitudes, crops and varieties need to be selected carefully in order to match the combination of temperature and LGP, because at lower temperatures crops usually take longer to mature. The climate of the southern tip of Africa is sub-tropical, but here also temperatures are not a constraint for 
crop production as long as crops and varieties are selected in accordance with the prevailing conditions.

\section{LGP: average, variability and pattern}

Where temperature requirements are met, crops must also be able to complete their growth cycle. Under rainfed conditions, it is the length of the period during which sufficient moisture is available that determines whether an economically useful yield can be obtained. This "length of the growing period" or LGP can be calculated on the basis of a water balance model, where inflows from rainfall are compared with outflows through evapotranspiration. Besides the LGP itself, its variability and pattern are informative. LGP-variability has obvious implications for the reliability of the climate but the LGP-pattern may even be more telling in this respect. If the usually rainy period contains breaks of some duration, the individual segments can become too short for crops to complete their growth cycle within one segment, while crops are unable to bridge the dry periods in between. For agriculture, the effect of such breaks very much depends on when they take place. If they come sufficiently late, the last LGP may refer to out of season rainfall if they come early they define a "false start", and most undesirable is obviously a mid-season break.

The only LGP-evaluation available at continental scale was calculated on the basis of mean monthly figures (FAO, 1978). Comparison of the LGP at a given location with the length of the growth cycle of any given crop variety gives a first impression of whether it would be possible to grow this variety at the location chosen and what its yield could be. However, such a comparison only refers to average conditions. Farmers tend to be highly concerned with climatic variability and pattern as well. For calculations of the LGP-variability and LGP-pattern it is necessary to study time-series and for this we have to rely on experience obtained in selected country studies: Mozambique (Kassam et al., 1982), Kenya (Kassam et al., 1991) and Nigeria (Keyzer et al.,1997). These case studies show that the LGP-variability tends to increase with shorter LGP's and that there are in general fewer breaks when the LGP is very long and when the altitude is higher. LGP-patterns are fairly constant spatially and over time since they are often related to overall weather patterns such as the bimodal tendencies of rainfall and the prevalent direction of moisture bearing winds on specific reliefs (e.g. windward slopes). We distinguish six climatic zones. 
(1) 0-75 days $L G P$.

This zone is hardly suitable for arable farming, because the LGP is generally too short for food crops, unless water sources other than rainfall are available (seepage, alluvial valleys). There are crops, notably millet, that can complete their cycle within 75 days, but the variability of LGP length in this zone is in general such, that many of the years would show a total crop failure, even for short duration millets. Conditions with an LGP $<75$ days prevail at the southern fringes of the Sahara, in large parts of Somalia and Kenya and in extensive areas of Southern Africa around the Kalahari

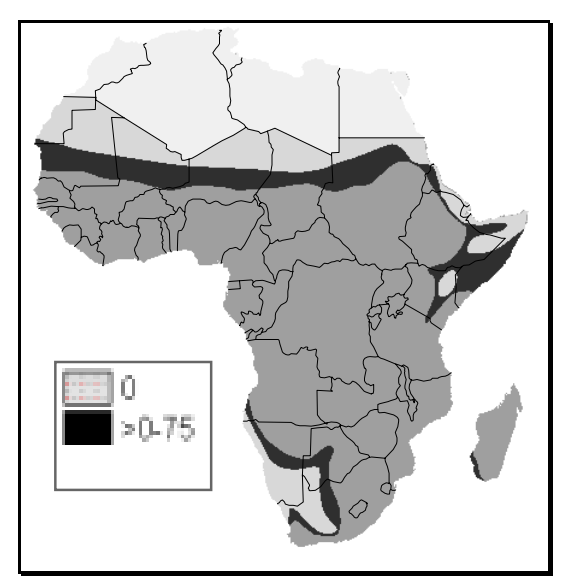

Figure 3. LGP 0 and 0-75 desert (Figure 3). These lands are mainly used for extensive grazing and locally, in oases, for agriculture.

\section{(2) 75-150 days $L G P$.}

Here the climate is suitable for arable farming but the crops need to be carefully selected so as to match climatic conditions. The farmer is faced with a problem of finetuning the system to combine adequate yields with sufficient reliability of supply. At sites where the LGP-patterns are reliable, i.e. have no breaks in most of the years, this zone is suitable for short duration annual crops such as cereals and legumes. As regards cereals, the growth cycle ranges from 60-90 days for millet varieties, 90-120 for sorghum and 90135 days for tropical maize. Yield potentials also increase in

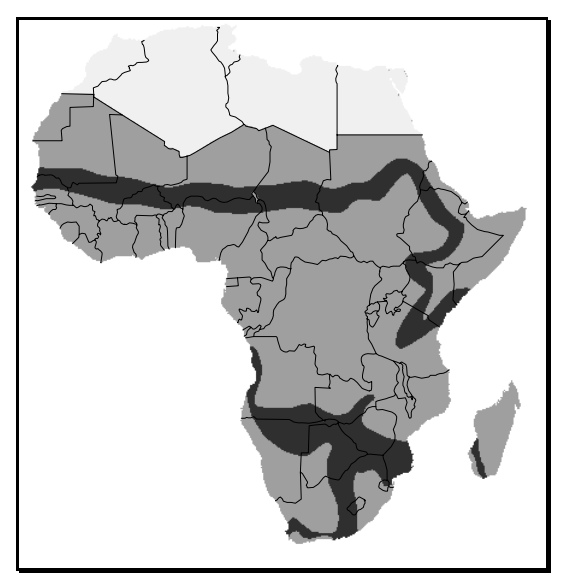

Figure 4. LGP 75-150 this order. For a given species, the longer duration varieties are higher yielding, but if the LGP is short, they are more risky as compared to varieties of shorter duration. Millet is often said to be drought resistant, but it is more accurately characterized as "drought evading" through its short duration. Sorghum is also said to be drought resistant, but for optimal growth its water requirements are similar to those of maize (FAO, 1979). The main difference is that sorghum performs better on poor soils.

The use of short duration millets remains risky up to an LGP of 100 days but above 100 days these varieties provide a stable food supply, though yields are low. High and secure millet yields can be obtained from varieties of longer duration, if the LGP exceeds 120 days. For sorghum and maize this reliability limit lies at about 150 days. 
The essential fine-tuning of farming systems in the 75-150 days LGP zone (Figure 4) is based on transfer of age old experience across generations. Farmers often maintain a portfolio of species and varieties with cycles of different lengths and vary the planting date. This practice spreads the risk and smoothens the peaks in labour requirements but it amounts to accepting yield reductions or underperformance on part of the planted area, as well as wastage of part of the applied fertilizer.

The discussion so far refers to crops and varieties that are not sensitive to day-length. In practice, farmers often include photo-sensitive varieties, particularly of sorghum and to a lesser extent of millet, in their cropping system. These are effective when LGPs are longer than the growth cycles of the photo-insensitive varieties. Within this zone they are therefore only used near the upper limit of 150 days and extend far in the next higher LGP zones (Kowal and Kassam, 1978). Photo-sensitive varieties are very locally adapted and they mature, in response to changes in day length, within a narrowly defined period that coincides with the end of the rainy period. Such varieties are particularly suited to conditions where the onset of the growing period is variable but its end is relatively stable. When planted at the beginning of the season, they can exploit the full duration of the growing period and mature and ripen under optimal conditions, when moisture is still available for seed setting and the dry atmospheric conditions are ideal for ripening. Photo-sensitive varieties are used in large parts of West Africa and also for example in Northern Mozambique.

As regards the LGP-pattern, the occurrence of breaks has often dramatic consequences in this zone, because the individual LGP-segments tend to become too short. In southern Africa the LGP-pattern is very irregular in this zone, with frequently three or even four very short LGPs within one year and an entirely unpredictable location of breaks in time (Kassam et al., 1982). Consequently, population density is very low and crop cultivation is mostly restricted to lowland areas that receive supplementary water from other sources than rainfall. Land use is often limited to livestock and minor forestry activities. In East Africa, the LGP-patterns are more regular, also over time, because rainfall has a fairly stable bimodal pattern. Yet the individual components of the LGP-pattern are short and land use is therefore similar to that in southern Africa.

An important part of the 70-150 days zone is the West African Sahel, where droughts have regularly caused famine, particularly in the last three decades. Here the population density and the spread of arable farming are relatively high, despite the short LGP and high LGP-variability. This is possible because the LGP-pattern is favourable, with few breaks and good moisture conditions during a substantial part of the growing period . Moreover, the incidence of human diseases is moderate. However, since 1970 the LGPs have shortened and moisture supply during the LGP has become less favourable (Voortman, 1998). 
In this LGP zone (Figure 5), optimal growing conditions for millet continue up to 180 days and for sorghum and maize up to 210 days. LGP-variability is much less pronounced than in the 75-150 zone and the total LGP is sufficiently long to sustain the varieties that have the longest growth cycle and are most productive. Indeed, from an agro-climatic perspective this zone has the potential of becoming the granary of the African continent. Main constraints are climatic reliability and soil conditions. Though soil quality varies, most soils are base-saturated and have a good

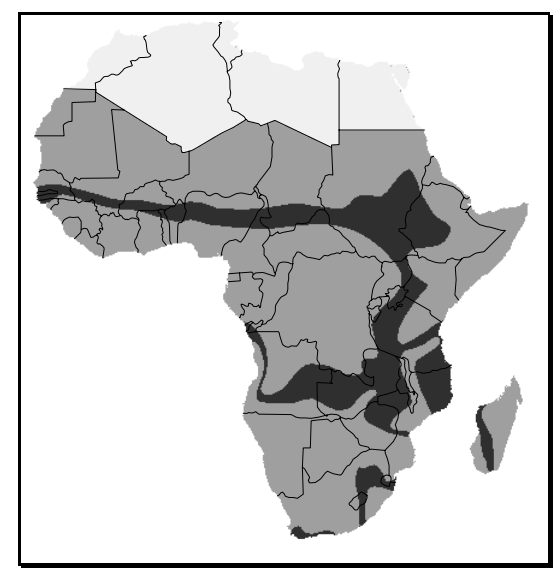

Figure 5. LGP 150-210 capacity to retain added fertilizers. Here high technology agriculture would allow for a three- to fourfold increase in cereal yields.

Generally, the effects of LGP-breaks very much depend on their predictability. Unpredictable breaks that refer to false start conditions can easily be overcome by replanting at the beginning of the main season since it will usually be sufficiently long. Far more problematic are unpredictable mid-season breaks. The crop may then be lost in the first season and the duration of the second season may be insufficient for a second crop. As in the previous zone, the highest population densities are found in areas with a stable climate with one uninterrupted growing period every year (e.g. Southern Niassa province in Mozambique). Second are areas with infrequent false starts in the higher part of this LGPrange (e.g. Nampula Province in Mozambique). Population densities are lower in areas of the lower LGP-range where false starts or mid-season breaks occur frequently (e.g. Central Lowland in Mozambique).

The situation is very different if there is more than one season in most of the years and one continuous season is the exception rather than the rule. Farmers will then select crops, usually of short duration, that suit the common length of the individual seasons. Alternatively, they can grow cassava because it will survive the dry spell and resume growth in the second season. Such conditions prevail in parts of equatorial East Africa where the rainfall pattern has a pronounced bi-modal tendency. 
The common cereal grains and legumes can still be found in the lower range of the 210-300 days zone (Figure 6) but as LGP increases pests, diseases and weed competition, and other climate related constraints become a problem. For millet, rainfall could wash away the pollen, thus reducing seed production. For sorghum, the occurrence of head mould, which makes the grain unfit for consumption, becomes more frequent. More generally, humid conditions at and beyond harvesting cause difficulties in terms of handling and storage of produce, and mechanization is

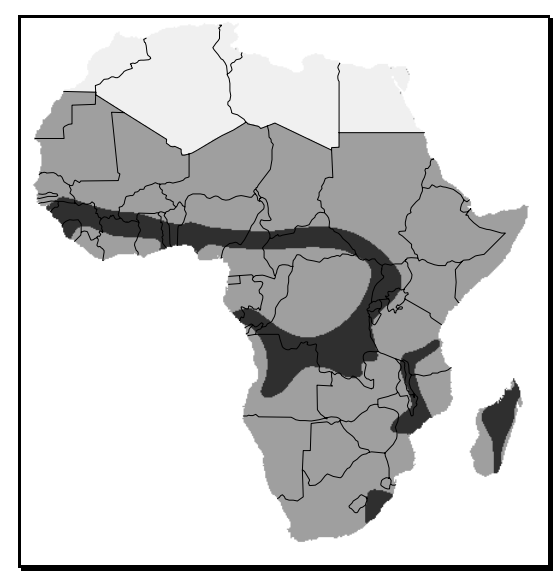

Figure 6. LGP 210-300 hampered if the soil is wet. Millet and sorghum are more affected by humidity than maize and therefore disappear earlier as the LGP becomes longer. They are being replaced by root crops such as yam and cassava. These $\mathrm{C}_{3}$ crops are, per unit of time, less productive in terms of dry matter formation than the $\mathrm{C}_{4}$ cereals, but they compensate this limitation by a longer growth cycle. In addition, these crops are also better adapted to the generally lower fertility levels of soils in this LGP-zone.

In the wetter part of this zone, one can see the perennial crops appear, particularly those that require relatively high fertility levels (e.g.cocoa, banana/plantain) and those that are sensitive to high aluminum levels in the soil, which are fairly common in the more humid zone. Crop performance in this case exhibits a trade-off between the yield reduction due to a relatively short LGP and the positive effects of higher soil fertility levels.

With increasing LGP-length, breaks in the growing period have less impact on food security but they still affect the farming systems. A false start in this zone leaves sufficient time for a main season crop. Mid-season breaks may even be beneficial, at least if short duration annual crops have been sown at the beginning of the first season, because these meet with better ripening conditions and a second crop can be grown after the break. Cassava is productive in this zone because of the generally long LGP and its capability to survive dry periods in case of breaks. Perennial crops are less affected by breaks, because their deeper rooting enables them to tap additional soil moisture that is beyond the reach of annual crops. 
In the most humid zone (Figure 7), cereals are near absent, except green maize, and root crops form the most important staple. Shorter duration yams (White Yam) can be replaced by species of longer duration (Yellow Yam). Farmers mainly grow crops for their own subsistence only, because climatic conditions restrict their possibilities for commercial production of annual crops due to the difficulties in handling and transporting the produce. The humid climate is usually associated with poor soils as rainfall causes leaching of plant nutrients and the high aluminum content of the soil

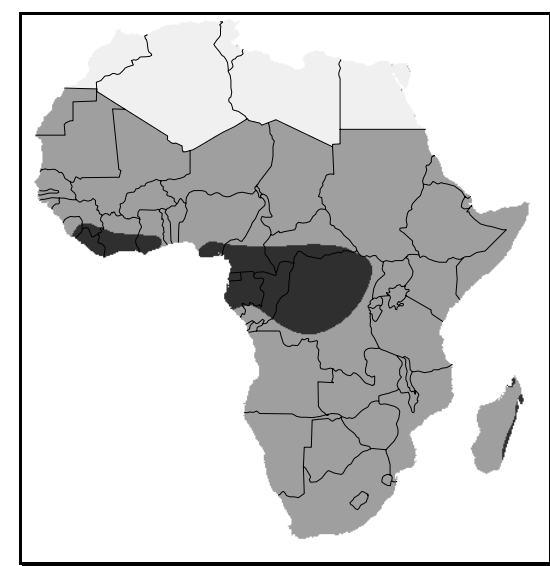

Figure 7. LGP $>\mathbf{3 0 0}$ negatively affects most crops. Moreover, these soils have a poor capacity to retain added nutrients. Consequently, the vast humid Congo basin has a low potential, particularly for high input, mechanized agriculture. Yet, at dispersed locations, soils can be of better quality, in addition to root crops allowing for banana and plantain cultivation as staple food, and cocoa as cash crop. Perennials suited to the humid conditions and associated poor soils are oil palm, rubber and tea, provided that the acidity is not extreme and aluminum levels are not excessive. In this zone, under lowland conditions, the occurrence of breaks becomes rather unlikely and their effect on crop production and farmer decision making would also be limited, given the predominance of cassava and perennial crops.

\section{(6) Areas at higher altitude and extra-tropical areas}

Figure 8 (Source: EROS, 1998) shows the relief map with zones at higher altitudes that are, like the extra-tropical areas, often perfectly suited for cultivation of crops which match the lower temperatures. Temperate crops like wheat, barley, potatoes and Phaseolus beans are well adapted to a relatively short LGP (150-180 days) at between 17.5 and 20 degrees C, but when temperatures become lower, they need longer to reach maturity. Temperate varieties of maize and sorghum can be grown as well, but these require longer LGPs than tropical

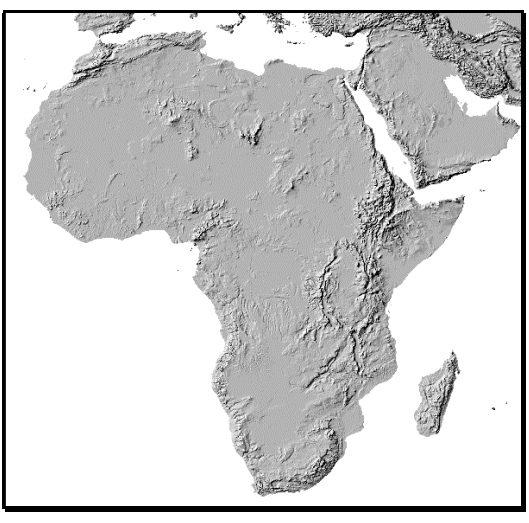

Figure 8. Relief map varieties under warm conditions and may have a crop cycle duration from 120 up to 300 days, depending on the temperature. If water supply is adequate, higher altitude areas are well suited to grow perennial crops such coffee, tea and bananas. Here LGP-breaks, if they occur, are more serious for annual crops than under lowland conditions because of the longer growth cycles of crops. However, cool temperatures also reduce evapotranspiration rates. Rainfall may therefore have a pronounced bimodal pattern and yet allow for a single uninterrupted growing period because the stored soil moisture is sufficient to carry crops through periods without substantial 
rainfall. The areas concerned mostly have a good potential, as reflected in high population densities. Attainable yield increases through improved technology are of a similar order as those of the warm tropical areas, i.e. three to fourfold.

\section{Summary}

To sum up, while temperature and LGP are important determinants of the crop and variety selection by farmers, the LGP-pattern and variability greatly affect their site selection. Consequently, the current land use distribution is in general such that moisture supply is sufficient and reliable for the commonly grown crops except in 75-150 days zone, where irrigation can be used to cope with LGP-variability and breaks, provided that suitable soils and water are available. Irrigation can also play a role in the 150-210 days zone if LGP-breaks occur frequently and if farmers want to grow off-season crops. This is further discussed in section 6 .

The LGP and temperature characteristics impose rigid but relatively high upper bounds on the agricultural potential of Africa but obviously, plants need more than water, heat, sunshine and atmospheric $\mathrm{CO}_{2}$. They also require nutrients to be supplied either by the soil itself or by the farmer. Eventually, the main technological challenge for agriculture in Africa is thus to find packages of high yielding varieties, fertilizer inputs and soil management practices that make full use of the climatic potentials. However, in the medium term the challenge is not to reach maximum yield but to achieve yield improvement, preferably through technologies that do not require vast amounts of external inputs, and hence depend on local soil conditions.

\section{Soil properties and land use}

We view soil properties in their environmental setting as resulting from soil formation processes which are governed by the factors climate, topography, parent material, vegetation and time (Dokuchaev, 1893; Jenny, 1980). Of the various aspects of soil properties, our discussion emphasizes soil chemistry because when water supply is adequate, it is primarily the availability of plant nutrients in the soil that determines agricultural production, at least under the low input conditions that are common in Africa. Moreover, the chemical constitution of the soil determines the extent to which added nutrients are retained and remain available for plant uptake.

We focus on the question whether the Green Revolution technology that was successful in Asia is suitable for African land resource conditions. To put this question into perspective, we start with a broad comparison of soils and soil formation factors in Asia and Africa, with occasional reference to Latin America, and subsequently characterize the African soils in some more detail. The discussion at continental scale is based on topographic maps (Philip, 1981), geologic maps (Bederke and 
Wunderlich, 1968), maps of population densities (EagleInc, 1990; Deichmann, 1997; Spiess, 1997), AEZ studies (FAO, 1978, 1980,1981) and the soil map of the world (FAO/UNESCO, 1973).

\section{Asia}

Most striking on the topographic map of continental Asia is the large massif of the Tibetan plateau with on its Southern fringes the Himalayas. At these high altitudes, the rock materials under the soils are, on a geological scale, of relatively young age, particularly if compared with the African continent, which largely consists of so-called Basement Complex, which is of old age (pre-Cambrian). The soils of the Asian highlands are shallow and young Lithosols with a rich mineral reserve, that reflects the nature of the parent rock underneath. This large Asian massif is the source area of many and very large rivers, which have deposited sediments consisting of upstream soil materials in large alluvial areas that are of Quaternary age (mainly Holocene).

The alluvial sediments thus consist of relatively rich materials, that continue to weather and supply the soil with mineral plant nutrients. In terms of soil classes, the older alluvial deposits consist of Cambisols and Luvisols and the more recent ones are called Fluvisols, all of which are generally rated as having a good agricultural potential, because of their high fertility. Furthermore, the depositional origin results in nearly flat topography, reducing the risks of erosion and facilitating the development of irrigation systems. The nearby rivers themselves constitute vast water resources that can be tapped for irrigation if rainfall is either insufficient or unreliable, and make it possible to grow crops outside the rainy season. In parts there is even an excess of water (Gleysols), and soil drainage is required. Most importantly, these alluvial deposits consist of strata with different properties that are related to different time periods and upstream origin of the sediments, and within one stratum the deposited materials are also derived from different locations in upstream catchment areas. Hence, these soils are developed in a mix of young parent materials with a rich mineral reserve, which can upon weathering, supply a broad array of essential plant nutrients, including micro-nutrients.

In South-East Asia, the Basement Complex that dominates in Africa is virtually absent as well. On the islands of Indonesia and the Philippines, parent rock materials are mostly even younger than on the continent and of Mesozoic, Tertiary and Quaternary age. They include Neozoic volcanic rocks that weather to good agricultural soils (Andosols, Nitosols or other types with a humic topsoil) that support very high population densities. On the mainland, volcanic materials of similar age occur in small extents in Southern Vietnam and Cambodia. Larger tracts are found in Southern China. In India, the extensive basaltic Deccan Plateau represents parent material of the same origin, and is one of the largest areas of Vertisols in the world, that can, with appropriate management, support good crops. As in the alluvial areas, the volcanic parent materials are of relatively young age, soils have a large mineral reserve and the parent material often consists of layers of different materials (tuff, volcanic 
ash, lava) that differ in both origin and chemical composition, and are likely to provide a broad spectre of plant (micro-) nutrients.

In both cases the soils were developed on relatively young geological formations consisting of mixed parent materials, that have a large mineral reserve, and where weathering produces a steady, albeit slow, supply of fresh plant nutrients. Under these conditions the highest population densities of the world could be found long before the Green Revolution. It was also here that the Green Revolution has been most successful. The technology used was based on high yielding varieties that are responsive to macro-nutrient (NPK) fertilizer, and this rather simple fertilizer strategy may have been successful only because of the mineral reserve of other essential plant nutrients available in this type of soil. Indeed, Green Revolution technologies are currently showing a yield decline in Asia. For rice experimental plots already produce yields that are lower than in the 1970's (FAO, 1998). In China, the balance among the macro-nutrients applied becomes an increasingly important factor (Jiyun and Guilan, 1995), whereas in India the sustainability of yields critically depends on judicious application of micronutrients (notably Zinc and Sulfur; see Tandon, 1995). This may indicate that available micro-nutrients have been depleted by crop removal and that weathering rates have become insufficient to meet the micro-nutrient requirements of crops.

Yet, population densities are also relatively high in parts of Southern China, and South and East India on Basement Complex (BC), a metamorphic parent material of pre-Cambrian age, that is not of mixed origin, and therefore "locally homogeneous", where soils are old and hence in an advanced stage of weathering. This is exactly the geological formation that is dominant in Africa, but there with few exceptions, the population densities it supports are low. BC also appears in Indochina in isolated pockets but with population densities that are more comparable to those of Africa. Below, we return to this apparent anomaly.

\section{Africa}

The geological map of Sub-Saharan Africa first of all shows that, unlike all other continents, it has hardly been affected by geologic folding and, if compared with other continents, the predominance of the Precambrian Basement Complex is striking. There has been a gradual uplift and tilting of the landmass (e.g. King, 1951) but this did not result in large energetic differences that characterize the river profiles in Asia. The most important geologically young event was the Rift valley faulting, resulting in mere vertical displacements (uplift and tilting) of a relatively localized nature. It is therefore not surprizing that Africa has only few alluvial areas of young (Holocene) age. 


\section{Alluvial sediments}

In Africa, alluvial sediments (Figure 9.Source: FAO, 1995a) are derived from source areas that are much less heterogeneous than in Asia and where soils contain fewer weatherable minerals, because of their high age. In fact, traditional smallholders appear to stay away from large parts of some of the alluvial valleys. For example, the upstream valleys of the Niger and Benue rivers within Nigeria are almost devoid of peasant cultivation (Loxton-Huntings, 1977), while the downstream Holocene part of the Niger delta is not used presumably because of poor drainage, salinity and workability constraints (heavy textures). For

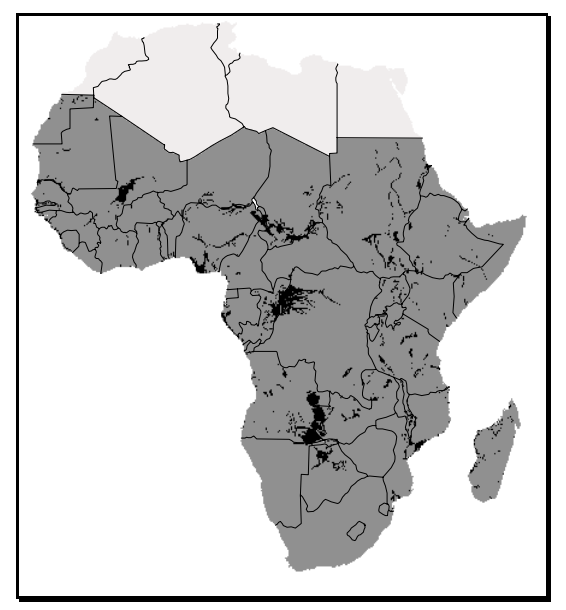

Figure 9. Alluvial soils and poorly drained soils similar reasons, the large delta of the Zambezi is only very locally in use (Snijders, 1985). Densely cultivated areas of alluvial origin do occur for instance in the valleys of the Nile, Limpopo and Senegal rivers and on small, isolated areas elsewhere. The Nile sediments are mainly derived from Mesozoic volcanic parent materials of the Ethiopian highlands and therefore still have a weatherable mineral reserve. This kind of parent material also occurs within the Limpopo catchment in Southern Africa. It seems that alluvial soils are more favorable if they are related to rock materials younger than Basement Complex. The inland Niger delta in Mali is a clear case in point.

Older deposits of early Quaternary and Pliocene (late Tertiary) age can be found at somewhat higher elevation in association with the Holocene Niger delta. They extend westward in a coastal strip up to Ghana. These deposits produce good soils (Nitosols), and this area supports some of the highest population densities in Africa.

\section{Volcanic materials}

In Africa volcanic parent materials are of Mesozoic age and hence mostly older than in Asia, but similar favourable soil types have developed (Nitosols, Phaeozems, Vertisols, frequently with humic topsoils). Whenever climatic conditions allow agriculture, the regions where these parent materials occur are as in Asia densely occupied: the Ethiopian highlands, the Kenyan highlands, Kilimanjaro, Northern Mara and Mbeya in Tanzania, the area of Eastern Congo, Rwanda and Burundi, Madagascar and South-West Cameroon (Figure10, Source: FAO, 1995a). The low population

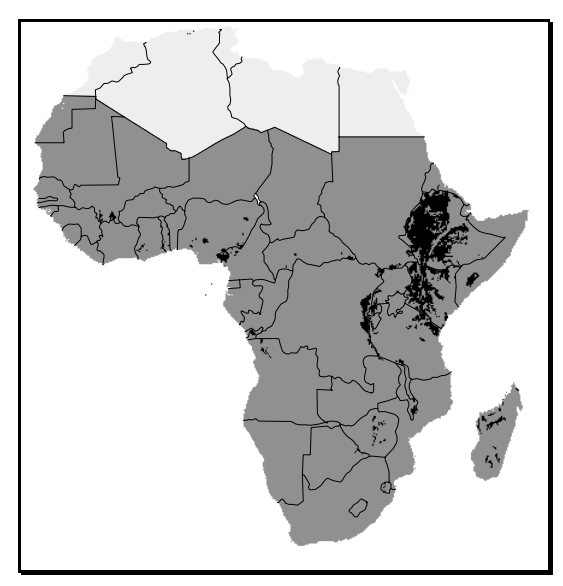

Figure 10. Volcanic soils 
densities on this parent material in parts of Tanzania, Kenya, Ethiopia and Eritrea are a reflection of low and erratic rainfall.

Sands

Unlike Asia, Africa has large areas of relatively young sandy parent materials (see Figure 11; source: FAO, 1995a). These are mostly of aeolian origin. Vast expanses of late Tertiary and Quaternary sandy deposits occur inland in West Africa south of the Sahara desert, where they partially and with

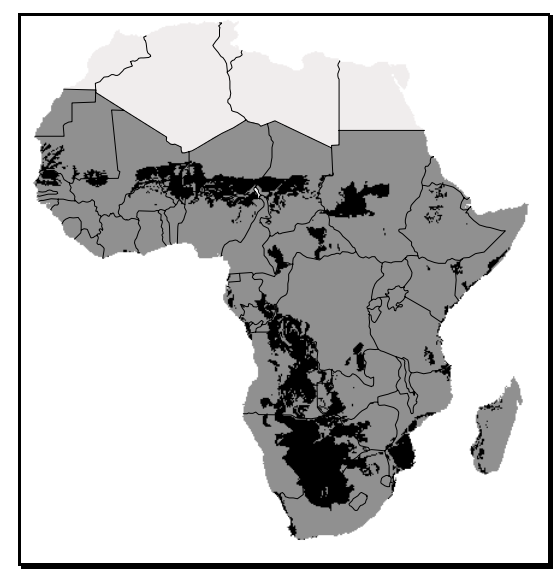

Figure 11. Sandy soils varying depth cover older and heavier textured Tertiary parent materials as well as Basement Complex. They derive from freshly weathered rock in the Sahara desert. Parts of this area support, rather unexpectedly, very high population densities, despite the dry Sahelian and Soudanian climate, for instance around Kano in Nigeria, parts of Sokoto state and adjacent Niger, the Mossi plateau in Burkina Faso and in Senegal. At some locations farmers apparently prefer to cultivate sandy soils above soils with a heavier texture but they discriminate within sandy areas as well. This needs some further explanation.

Due to age differences, coversands differ widely in weathering stage and grainsize distribution (sorting). The sandy deposits of older age, are chemically poor and therefore mostly avoided for cultivation. But also among the better sandy soils there are important differences in land use intensity which are related to the grainsize distribution of the cover sands (Sombroek and Zonneveld, 1971). The older cover sands have a less sorted grain size distribution that, upon the impact of rainfall at the start of the season, causes the toplayer to seal, reducing the infiltration. On the younger cover sands, rain water infiltrates readily, even if it occurs in heavy showers. Where the latter is the case, farmers tend to choose sandy soils above heavier soils derived from Tertiary sediments and Basement Complex. This is because, despite their low waterholding capacity, sandy soils with good infiltration properties store water at deeper layers and are, therefore, physiologically less dry than heavier soils, particularly if deep rooting crops like millet are used (dustmulch effect, see Walter, 1984). Moreover, in sandy soils plant nutrients are more readily available for crops than in soils of heavier texture (Boyer, 1978; MinCo, 1980).

The Kalahari Sands, which cover a vast area in the western interior of the continent from Botswana up to Congo, are of Tertiary age and hence older than most of the West African sands and derive from more weathered sources. They only support low population densities. The dominant soils in the more humid north are very poor (Ferralic Arenosols). In the southern parts soil quality is somewhat better (Cambic Arenosols), but here climate is mostly too dry for rainfed cultivation. We also mention that on sandy windblown deposits land use tends to be more intensive on young deposits of mixed origin. 


\section{Basement Complex}

It appears to be a distinguishing feature of Africa that more than half of its agricultural land consists of soils derived from Basement Complex rock (Figure 12). Basement Complex consists mainly of metamorphic rocks dating back to the Pre-Cambrian period and the soils are consequently of old age as well. Hence, one commonly associates Basement Complex with deeply weathered, poor and leached soils.

\section{Land ecology of African Basement Complex}

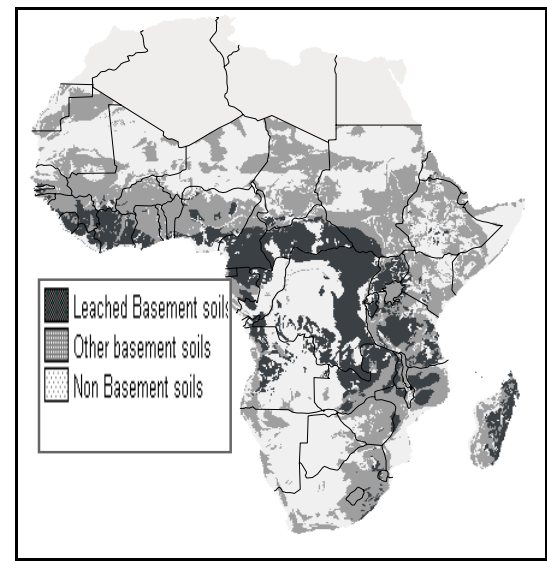

Figure 12. Soils of the Basement Complex

While some of the poorest soils of the world can be found on Basement Complex, for instance in the humid interior of Brasil, at the same time this geological formation supports relatively high population densities in parts of coastal Brasil, in Southern India and also in parts of Africa. This needs further explanation.

\section{Spatial variability of soils on Basement Complex}

In fact, the dominant soil types on Basement Complex vary significantly. One explanatory factor is climate. Various kinds of poor and leached Ferralsols are dominant in the wetter part with long LGPs, while under shorter LGPs Ferric Luvisols become dominant. Although the latter are not of high fertility, they contain weatherable minerals, and are base-saturated and thus hardly affected by leaching. Ferric Acrisols take an intermediate position but their extent is limited in Africa.

More specifically, in the zone with an LGP above 300 days Ferralsols prevail and the vegetative cover consists mainly of tropical rainforest. These are the true humid lowland conditions with very poor and acid soils that frequently contain Aluminum at toxic levels and may fixate applied phosphate. Population density is generally very low, except locally on non-Basement parent rock materials. We will not further consider this zone because the environmental conditions are not suitable for low cost intensification of agriculture (it may be mentioned that this LGP-zone includes a large non-basement area in the Congo basin, with light textured soils (Xanthic Ferralsols) that are much poorer than related soils on Basement (Orthic Ferralsols) that we also disregard).

In the zone with 210-300 days $L G P$, there is an important difference in terms of prevailing soil types between West Africa and the rest of Africa. In West Africa Ferralsols and Acrisols are dominant, 
especially in the western part, but Ferric Luvisols also occur throughout this zone and in Benin and Nigeria they even dominate. The wetter parts of this zone still support (remnants of) rainforest but with decreasing LGP there soon is a transition to more open savannah woodland, particularly on Ferric Luvisols. In this part of West Africa and particularly in Nigeria the population densities are well above the African average, presumably due to the relatively reliable rainfall conditions (Kowal and Kassam, 1978), but the relatively good soil fertility conditions might play an important role as well. In Central, East and Southern Africa, the extent of Ferric Luvisols is very limited in this LGP zone and Ferralsols are dominant. However, there hardly is any rainforest and extensive areas mapped as Ferralsols in Zambia are for instance covered with Miombo woodlands (Wild and Fernandes, 1967), and parts of Shaba are even covered by open Acacia savanna (Mullenders, 1954). This suggests, given the environmental conditions under which similar vegetation formations occur elsewhere, that the levels of soil fertility could be higher than on the Ferralsols of the rainforest zone of the humid tropical lowlands. Though population density is generally low, important, dispersed concentrations can be found, for example in Angola, Shaba, Eastern Congo, the Lilongwe plain in Malawi and parts of the area surrounding Lake Victoria in Uganda and Kenya. These areas have three characteristics in common. First, Acacia and Combretum appear as natural vegetation (Mullenders, 1954; Lind and Morrison, 1974; Trapnell and Langdale-Brown, 1972; Wild and Fernandes, 1967). Secondly, they are located at some altitude, where the incidence of human and animal diseases is lower and environmental conditions are often better. The climate is usually more reliable, because the reduced evapotranspiration rates allow crops to continue growth on the basis of soil moisture during dry spells. Leaching rainfall is usually less if compared with growing periods of similar length under lowland conditions and the lower temperatures reduce the decay of soil organic matter. Thirdly, soil parent materials also seem to play an important role. For instance the soils of parts of Shaba and Eastern Congo (Rhodic Ferralsols) are unusually fertile for the prevailing climatic conditions and these soils usually occur on non-acid parent rock materials (e.g. Van Wambeke, 1974). In East Africa, soils underlain by Basement Complex rock are enriched with volcanic ashes (e.g. Wielemaker and Boxem, 1982).

Under drier conditions ( $L G P<210$ days), Ferric Luvisols of somewhat higher fertility are the typical soils on Basement Complex and increasingly rainfall reliability becomes a limiting factor. In West Africa, as in the previous LGP-zone, the relative reliability of the climate finds expression in above average population densities. Elsewhere, the stable climates of highlands are preferred or, as in the case of southern Africa (South Africa, Zimbabwe and Mozambique) specific locations are selected on South-East, windward facing, slopes, where the risk of dry spells is limited. However, also within the areas of reliable rainfall, population densities differ significantly. Very high densities are mostly found on favourable soils (Chromic Luvisols, Nitosols, Phaeozems) that only prevail at specific locations. For example, in a detailed study of the Angonia district in Mozambique the differences could be attributed to the parent rock material (Voortman and Spiers, 1986). Here the favourable soils (Phaeozems) are derived from charnokitic rock which although metamorphic, has chemical properties 
close to volcanic rocks (Mason, 1978). It is precisely this type of rock that occurs extensively in India (Nockolds et al., 1978) where Basement Complex more generally supports good agricultural soils and high population densities.

In short, Basement Complex parent rock does not necessarily lead to poor and leached soils (Figure 12; source: FAO, 1995a). In fact, leached soils cover only 14.7 percent of the African continent and this compares favourably with South America (37.2 percent) and tropical Asia where leached soils cover 18.3 percent (FAO, 1991). The discussion also showed that ecological differences of relevance to agriculture may not be fully captured by the system of soil classification. With respect to population densities, site selections by farmers in general correlate with altitude, reliability of rainfall and soil fertility. High population densities can often be attributed to unusually high soil fertility, which in turn relates to altitude and the properties of the parent rock, and correlates with natural vegetation.

\section{Local homogeneity of soils on Basement Complex}

The mineralogical composition of metamorphic rocks follows, at any given location, from the nature and composition of the original source materials and the process, circumstances and degree of metamorphosis. Depending on its formation history, Basement Complex rock may be rather homogeneous over large areas but it may also show banded patterns with different rock types at short distances. How this appears at the surface also depends on the angle of tilt of the bedrock formations. Strongly banded rocks that occur at near vertical tilt may show rapid alternations of poor and good soils with a bandwidth in the order of 10 meters.

The fundamental distinction between Basement Complex rock, volcanic and alluvial parent materials is that the soils on Basement Complex are not sedimentary and therefore not of mixed origin at any given location, as opposed to the alluvial, volcanic and sandy soils. The essential plant nutrients $\mathrm{P}, \mathrm{K}$, $\mathrm{Ca}, \mathrm{Mg}, \mathrm{S}$ and micro-nutrients become available upon in-situ weathering of a single parent rock type and weatherable minerals derived from it that are still available in the soil. Although the availability of nutrients is also affected by climatic conditions, the proportions and consequently the (im-)balances, deficiencies or toxicities are essentially determined by the parent rock at every location. Agriculture tends to exacerbate existing imbalances and deficiencies because it removes nutrients while the soil has a low capacity to renew nutrient supplies due to its advanced stage of weathering.

\section{Summary}

We conclude that in Africa, as in Asia, high population densities occur on good soils derived from relatively young geological formations of alluvial and volcanic origin that consist of mixed materials 
with a substantial weatherable mineral reserve. However, outside East Africa, the extent of volcanic areas is very limited. Alluvial areas are also much smaller, and their quality is only high in the Nile valley, and along small stretches elsewhere. Africa also differs from Asia by its large areas of sandy deposits, where formation history and age also seem to be a decisive determinant of land use. The main difference is that half of the agricultural land in Africa consists of soils derived from Basement Complex rock, which have the distinguishing property of combining spatial diversity with local homogeneity, because they are not of mixed origin.

\section{Fertilizer Strategies}

African farmers are often well aware of the potential contribution of mineral fertilizer to crop production. Yet fertilizer use is low and the main reasons for this are lack of confidence in economic returns and lack of knowledge as to the kinds and rates of fertilizer to be applied, given the crop to be grown and the local agro-ecological conditions (Smaling et al., 1992). In fact, fertilizer recommendations are usually formulated for very broad regions, if not entire countries (Sanchez et al, 1992; IOV, 1995).

The discussion of land use patterns in relation to land resources showed that the dispersed settlement patterns in rural Africa reflect the heterogeneity of Basement Complex and through it of local soil chemistry. Therefore, it seems unlikely that such blanket fertilizer recommendations, say at national level, will be effective.

As mentioned earlier, the common fertilizer recommendations often refer to the macronutrients $\mathrm{N}, \mathrm{P}$ and $\mathrm{K}$ either individually or in compound form. Macro-nutrient fertilizers are very effective when it comes to replacing the nutrients most used by crops and thus removed from the soil in intensive cultivation systems. However, at the early stages of fertilizer application, currently prevailing in most of Africa, fertilizer should not be aimed at replenishing nutrients removed but primarly serve soil to correct chemical imbalances and deficiencies (e.g. Dudal, 1998). In fact, non-replacement of a nutrient in excess supply could even be beneficial for future yields.

The application of macro-nutrient fertilizer, as used in the common Green Revolution technology, is often presented as a quick, sure and efficient way to raise crops yields. However, the factual evidence is different. In Nigeria, results from a survey referring to 11 crops, covering a large part of the country, show that macro-nutrient applications resulted in lower yields in 44 per cent of the cases, yield increases were less than 20 per cent in 25 per cent of the observations and only in 12 per cent of the cases did yields increase by more than 50 per cent (APMEU, 1987). Woodhouse and Rendle (1983) report on fertilizer trials at many locations in Mozambique and nowhere found any response to Potassium. Response was positive with respect to Nitrogen in almost all cases (except for cotton) with

respect to Phosphate in only about 50 per cent of the cases. In a study on Kenya deficiencies (positive 
response) of $\mathrm{N}$ and $\mathrm{K}$ were reported in only 57 and 26 percent respectively (KARI, 1994). In the case of Zambia fertilizer aid was instrumental in shifting towards hybrid varieties of maize, but it did not result in higher yields, and production increases obtained were merely attributed to area expansion (IOV, 1995).

One might argue that the fertilizer may have been polluted, that it was applied wrongly, that it was diverted to other destinations, and so on. However, the findings are confirmed by in-depth agronomic research. Smaling et al. (1992) only consider N and P, but they convincingly show that macronutrients can be ineffective in specific agro-ecological conditions. Other research shows that macronutrient application only becomes effective if the existing soil deficiencies or imbalances are addressed at the same time. In Zimbabwe research was undertaken with the objective of designing a profitable smallholder enterprise (Rodel and Hopley, 1973). It appeared that the mere application of N-P-K fertilizer was unprofitable, because crop yields remained at low levels. The application of N-P$\mathrm{K}$ in combination with minor amounts of Boron and Zinc resulted in yield increases for maize of 167 percent (from 24 to 64 bags). Cotton treated with N-P-K, dolomitic lime (containing $\mathrm{Ca}$ and $\mathrm{Mg}$ ) and Boron led to yield increases exceeding 400 percent. Similar results from micro-nutrient application were obtained elsewhere in Africa. For instance the application of very minor amounts of Copper caused yield increases of 50 percent in Nigeria (Ojeniyi and Kayode, 1993). It was also shown that maize yields in Angonia (Mozambique) more than to N,P and K were related to the (cation) ratios $\mathrm{Ca} / \mathrm{Mg}$ and $\mathrm{Mg} / \mathrm{K}$ (Voortman, 1986).

Clearly, application of N-P-K in wrong proportions is always wasteful and the more so if some micronutrient is the actual limiting factor. But more serious than wastage is the possible detrimental effect of macro-nutrients on the availability of essential micro-nutrients. For example, increasing already high levels of $\mathrm{K}$ may cause Boron deficiency and applying $\mathrm{P}$ to Zinc-deficient soils enhances the deficiency and applying Zinc alone may affect P availability (e.g. Boyer, 1972, 1978, 1982). The application of macro-nutrient fertilizer needs to take into account such possible antagonisms with micro-nutrients. Therefore, the simple inclusion of all micro-nutrients, like vitamin pills, within a bag of macro-nutrients will not do.

In short, fertilizer recommendations should be more region- and ecosystem-specific and initially aim at correcting chemical imbalances and only those macronutrients should be applied that are clearly in short supply. Due attention should be given to imbalances between macronutrients, micro-nutrient deficiencies as well as possible interferences between nutrients. Although these principles are obviously important under all conditions where fertilizers are applied this is particularly the case on Basement Complex soils because, as was shown previously, soil chemistry reflects the homogenous (non-mixed) parent material which implies that imbalances, deficiencies and toxicities are more likely to occur and because these weathered soils have a low capacity to replace nutrients that become deficient through crop removal. 
The difficulty in applying fertilizer recommendations in Africa is that in view of the variability and spatial arrangement of land ecological conditions, the requirements are highly site-specific, and that, consequently, fertilizer strategies impose high informational requirements. Nonetheless, recent literature suggests that assessments of land ecological circumstances, which include the natural vegetation, potentially offer a powerful tool to establish a stratification of land types that is applicable to larger areas and is of relevance to the fertilizer needs of soils (Spiers, 1995). Although this tool is not fully operational as yet, there is a vast amount of information on soil resources and vegetation ecology available for the design of a spatially explicit fertilizer strategy.

\section{Irrigation}

Irrigation reduces the dependency on rainfall and could make an important contribution in drought prone areas (FAO, 1985; Barghouti and Le Moigne, 1990; FAO, 1995). Currently, irrigation with full or partial water control covers 5867000 ha which is only about four percent of total cropped area in (Sub Saharan) Africa. This is modest compared with the 24 percent in Northern Africa, 37 percent in Asia and 15 percent in Latin America (FAO, 1995). In Africa close to half of the irrigated areas were developed under formal schemes implemented by government agencies or by commercial enterprises, while the other half consists of traditional irrigation developed and managed at individual or at community level.

The reasons for the low share of irrigation are of both agro-ecological and institutional character. Agro-ecological factors include the erratic flow regimes of the main rivers, the relatively flat topography in the Western part of the continent which makes it more difficult to select appropriate dam sites, the patchy distribution of suitable irrigable soils, and finally the scattered location and low recharge rates of groundwater reservoirs. Institutional factors are the deficiencies in implementation of large scale irrigation schemes, such as the inadequacy of feasibility studies (Lele and Subramanian, 1990), high development costs in the range of 6-45 000 US\$ per ha and with an average of 20-30000 US\$, and isolated top-down planning (Diemer and Vincent, 1992).

The various problems encountered have led to a loss of interest on the part of national governments and foreign donors, as reflected in the reduced expansion of irrigation from 150000 ha annually during the mid-sixties to approximately 29000 ha in the period 1993-1996. However, the increased frequency of drought related famines in the last decades and the expected impact of climatic change

on the already water scarce regions unmistakenly call for a reassessment of these views (Klohn and Wolter, 1997). 


\section{Agro-ecology and irrigation}

Agro-ecological conditions affect the opportunities for irrigation. In the dryer areas (LGP 0-150 days), the main objective of agriculture is to produce a crop during the rainfed cropping season and, water availability permitting, to produce off-season crops as well. However, it is also in this zone that salinity/sodicity problems occur most frequently. Hence, even small scale local irrigation requires scientifically based advisory services. Under more humid conditions, irrigation aims at growing crops of a longer duration than the prevailing LGP or to grow a second off-season crop. Supplementary irrigation may be used to overcome dry spells in case these occur with some frequency within the normally rainy period. In this case it should be complemented by drainage control. When the LGP is near year-round, irrigation can be used to achieve full water availability during the entire year or to grow rice that needs flooding.

\section{Potentials and constraints}

The potential for large scale irrigation schemes is mainly concentrated in the alluvial valleys. However, in densely populated valleys, the development of new irrigation is constrained by current land use, and in the sparsely populated valleys the suitable soils tend to occur in dispersed or patchy patterns, making the development of irrigation infrastructure more costly. Irrigation development will commonly have to be initiated on currently unused land, where apart from soil fertility constraints, the flooding, poor drainage, workability constraints due to heavy textures and salinity or sodicity problems, and the possibly endemic diseases have to be taken into consideration and require detailed knowledge of local circumstances (FAO, 1985). The design and management of such irrigation systems often requires a quantum leap in farming technology, and tends to end up in dramatic failure.

In contrast, small scale irrigation mostly aims at improving water supply on currently cultivated lands, and is less demanding in terms of technology. Here a higher and more secure yield can be realized by mere combination of supplementary irrigation (e.g. through low-lift pumps) with relatively simple fertilizer packages (FAO, 1997a). If this irrigation relies on groundwater, water quality may pose a problem. Moreover, competition between agriculture, the industrial sector and household consumption is of increasing concern in some countries (FAO, 1995). Currently, the major part of the available water is used by the agricultural sector (50-90 percent) and can be extracted from internal renewable water resources such as rivers and groundwater reservoirs which are replenished by endogenous precipitation. For example, Niger, Somalia, Eritrea and Chad in the Northern Hemisphere, and Namibia and Botswana in the South still consume less than their available water resources but they benefit for their water use from important transfers of other countries $(\mathrm{FAO}, 1995)$. In Mauretania, water consumption already exceeds the internal water availability. Demands by consumers and industry will increasingly claim their share of the available water, and impose limits on 
water use in agriculture (Klohn and Wolter, 1997). Net exporters of water might also ask for financial compensation to be settled through international agreements.

\section{Water erosion}

The natural resources of Africa are not immutable. While fertilizer and irrigation strategies seek to develop them further, it is also necessary to consider resource conservation. This holds especially at sites where expansion and intensification of agriculture create distortions in the existing agroecological equilibrium that might induce land degradation processes.

In Africa, soil erosion by water (water erosion) constitutes the most serious and widespread land degradation phenomenon (Oldeman et al., 1991). Water erosion removes the fertile topsoil due to the impact of rainfall and subsequent overland-flow and can cause severe decline in fertility and deterioration of soil structure.

\section{Water erosion and productivity}

The effects of erosion on land productivity are particularly severe because it is the topsoil that is removed, which is usually of much higher fertility than the subsoil. The eroded material could be two to seven times more fertile than the original soil (Sabel-Koschella, 1988; Nill, 1996; Moyo, 1998). Soil erosion can to some extent be balanced by soil formation through the weathering of underlying rock. However, the rates of soil formation are in the order of $150-400 \mathrm{~kg} / \mathrm{ha} /$ year while soil erosion, if it occurs, easily surpasses 10 tons/ha/year (e.g. Lal, 1995). In fact, under common agricultural practice, soil erosion rates are frequently of the order of 50-150 tons/ha/year (Elwell and Norton, 1988; Roose, 1977; CDE, unpublished data) and extremes of 300-700 ton/ha/year have been reported for Rwanda under traditional farming systems on steep slopes (Roose, 1997). Proposed levels of 'Tolerable soil losses' range from 0.2 to 11 tons/ha/year (e.g. Lal, 1983; Hudson, 1986), depending on the prevailing agro-ecological conditions. These values clearly exceed the rate of soil formation and represent, accordingly, soil losses that guarantee a maintenance of crop production at acceptable levels for a period of about 25-50 years only (Morgan, 1995).

There are only few studies on Africa that quantify the influence of soil erosion on land productivity. Kaihura et al. (1998) demonstrated for a site in Tanzania that erosion decreased the production of maize and cowpea. Mbagwu et al. (1984) simulated the erosion process by desurfacing the top layer of the soil and found that maize yield declines with 95 per cent. Oyedele and Aina (1998) found declines in production potentials of 80 per cent and 65 per cent for slightly and moderately eroded

soils, respectively, in the South-Western part of Nigeria. Soil erosion also makes it more difficult to 
determine the appropriate fertilizer applications. Lal (1976) demonstrated for a site in Nigeria that an adequate dressing of major nutrients alone could not compensate the nutrient losses and that important micro-nutrients became deficient whilst others reached toxic levels. These examples illustrate the importance of soil conservation for maintaining existing productivity levels, let alone improving these.

The most recent continent-wide assessment shows that 494 million ha, or 22 percent of the agricultural land, (including rangelands), in Africa is affected by soil erosion by water (Oldeman et al. 1991). The study confirms common field observations that overgrazing is the main cause of soil erosion, followed by inappropriate cultivation techniques on arable crop land. In this context it is important to note that the number of cattle in Africa almost doubled in the period 1961-1994 while the area of grazing lands hardly increased (source: FAO-Agrostat, 1999). The expected intensification of use on currently cultivated lands, expansion of cultivation into more marginal areas, reduction in grazing lands and increasing numbers of livestock set the stage for serious erosion problems in the future.

\section{The process of soil erosion by water}

Water erosion is a complex process in which many factors are simultaneously at play. Major factors are rainfall erosivity, soil erodibility, topography, land cover and conservation measures.

Rainfall erosivity depends on the amount, intensity and other characteristics (raindrop size, angle of impact, etc.) of the individual storms. Rainfall has a direct effect on topsoils through the kinetic energy of raindrops and subsequently by erosive overland-flow. The latter occurs when rainfall intensity exceeds the infiltration rate either because of high rainfall intensity or because of saturated soil conditions. Compared to temperate regions, the erosive force of rainfall is more aggressive in tropical areas due to higher rainfall intensities (Kowal and Kassam, 1977; Lal, 1990) and larger raindrop size (Lal, 1987). Rainfall erosivity is higher in sub-humid and humid West and Central Africa than in most of East and Southern Africa (Fournier, 1962; Nill et al. (1996).

Soil erodibility refers to the degree of resistance of the soil against detachment and transport. It depends on a number of interacting topsoil properties such as soil texture, aggregate stability, shear

strength, and their interaction with organic material (Morgan, 1995). Soil erodibility is also affected by hydrological properties of the entire soil profile that determine the infiltration rates and permeability. 
Above all, soil erosion is associated with topography (see Figure 13; source: FAO, 1995a). It is well known that steep slopes cause higher velocities of overlandflow which in turn increases its erosive forces. Slope length also plays an important role because it determines to what extent water that runs off superficially will accumulate.

Land cover as determined by the temporal and spatial development of above-ground

vegetation and the degree to which the soil surface is

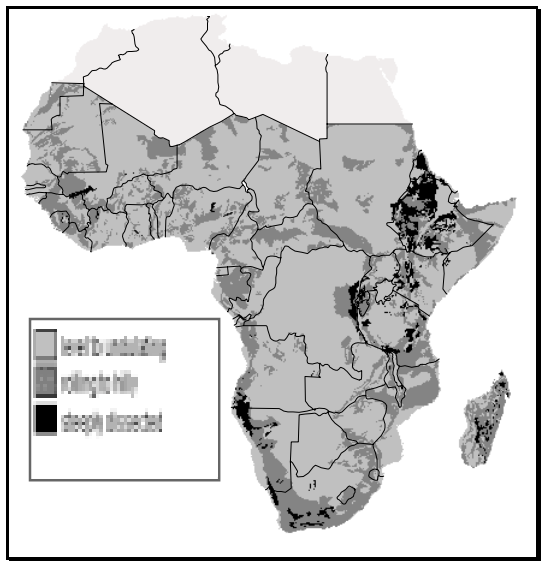

Figure 13. Topography/slopes covered with vegetative matter (mulch) is a major factor affecting erosion rates. It may be noted that the protection against water erosion operates mainly through the lower vegetation and litter on the ground rather than from trees. Similarly, in arable farming, crop residues in direct contact with the soil surface are the most important contributing factor to soil conservation.

Other soil conservation measures seek to reduce slope length and to evacuate excess water e.g. by contour bunds and grassed waterways. Under (semi-) permanent cultivation such measures are necessary on lands with slope gradients from 2 percent onwards. Up to about 15 percent, these relatively simple measures are adequate, but the interval at which they have to be constructed becomes shorter with increasing slope gradient, and they will then occupy a larger proportion of the land. Above 15 percent, conservation measures of another nature (e.g. terraces) are called for, which require considerable investments. The type of soil conservation measure and its efficiency in countering soil erosion obviously depend to a large extent on the land use that is being practiced. For example, in the range of 15-30 percent land without conservation works can be used for rangeland, provided that it is well managed and not overgrazed. From 30 percent onwards slopes should preferably stay under a cover of natural vegetation. Figure 13 shows that steep slopes mainly occur in the Eastern part of Africa, with an extensive area in the Ethiopean high lands.

\section{Soil erosion hazard and agro-ecological conditions}

The little amount of rainfall in the 0-75 and the 75-150 days LGP climatic zones implies low rainfall erosivity levels and yet isolated heavy showers can be highly erosive. The combination of short LGPs with prevalent sandy soils result in low levels of soil organic matter, and vegetative covers are reduced at the onset of the rains because of the long preceding dry season. The erodibility of sandy soils depends on the grain size. If grainsize is relatively uniform, initial infiltration rates are high but the low water storage capacity may cause overland flow during heavy showers. It the grainsize nonuniform heavy rains tend to result in surface capping and crust, wit reduced infiltration and increased 
overland flows and erosion risks. As the lands selected for cultivation are often less prone to erosion, these risks mainly relate to rangeland, though the flat topography in sandy areas partly compensates for soil the erodibility. Outside the sandy areas, the erosion hazard is somewhat higher, mainly because of more unfavourable topography and soil infiltration properties, including surface crusting. In these LGP-zones, important benefits in terms of crop production can be obtained from water conservation measures that are also effective in arresting soil erosion.

Rainfall erosivity increases in the 150-210 days zone and reaches particularly high levels in the zone of 210-300 days. In both cases arable lands are usually bare at the onset of the rains, but the number of days during which crops cover the soil is usually larger in the 210-300 days zone, compensating to some extent for the higher total rainfall erosivity. The common Basement Complex soils in these zones have a profile with rather unstable lighter textured topsoils covering heavier subsoils and this increases their vulnerability to erosion. Current land use is mainly taking place on soils where the conditions are favourable but severe erosion may result as new land is taken into use where the conditions are less favourable.

The humid zone of more than 300 days LGP clearly has the highest rainfall erosivity, but adapted perennial and long-duration annual crops usually protect soils well and there is in general an abundance of organic material that can be applied as mulch. In addition, the soils tend to be permeable and physically stable and therefore resistant to erosion (Deckers, 1993). However, improper site selection, poor agricultural practices and excessively intensive land use can result in serious erosion (e.g. Aneke, 1986). The effects on crop production are particularly severe in this zone because shallow topsoils overlay subsoils that contain very little plant nutrients.

\section{Soil and Water Conservation projects}

Though the importance of soil conservation goes unquestioned, past experience with soil conservation programmes is far from promising. Such programmes have often focused on constructing physical structures implemented in supervised schemes. Adoption by farmers seldom reached beyond the limits of the intervention area, suggesting that farmers are unable to implement them or do not experience any benefits. Important aspects that contribute to the failure of soil conservation adoption are insecurity of land tenure, communal land ownership, costs, time requirements and discrepancies of discount rates between aid agencies and farmers. Soil conservation works were usually abandoned when supervison was withdrawn and often become a main cause of erosion themselves (e.g. Showers and Malahleha, 1990). On the other hand, there are also reports of successes in implementing soil and water conservation works, for example in the Machakos district in Kenya where local people welcomed and successfully adopted soil conservation measures. The success is possibly attributable to the high population and land pressure combined with a good access for farmers to market outlets in urban areas (English et al., 1994; Tiffen et al., 1994). 
More generally, the 'people first' approach whereby farmers and experts jointly compile a list of priorities has become the ruling paradigm of soil conservation. The approach included the orientation on traditional cultivation techniques that were hitherto studiously ignored. Rey et al. (1998) suggest to take these existing soil conservation systems as a point of departure for improved farming. The advantages of the approach are obvious. The traditional techniques are fully adapted to the working calendar and labor differentiation by gender (Millar, 1998) and in general require no cash expenditures for either construction or maintenance, which facilitates their acceptance by farmers. Moreover, it appears upon closer inspection that traditional soil and water conservation apply exactly the same principles as the modern designs. A famous example can be found in Yatenga, Burkina Faso where improved planting pits or zaï are constructed that vary in diameter between 20 and $30 \mathrm{~cm}$, and in depth between 10 and $15 \mathrm{~cm}$ in accordance with the water storage capacity of the soil. The excavated soil is kept downslope and the water is collected from these new micro-catchments. The construction is simple and can be effectuated during the off season, and this may explain the widespread adoption of this technique in Burkina Faso (Ouedragao and Kaboré, 1998), Mali (Kassogoué et al., 1998) and Niger (Hassan, 1998). Other examples of successful traditional soil conservation measures are found in Tanzania (Mbegu, 1998) where heaps of compost are orderly placed so as to protect the soil and reduce the erosive velocity of the runoff during the start of the rainy season. The same principle was widely adopted on the central plateau in Burkina Faso (Slingerland and Masdewel, 1998). More complex physical structures such as the construction of stone walled terraces (Igbokwe, 1998) in combination with agro-forestry (Tchawas, 1998) also show the application of basic soil conservation principles in traditional techniques.

\section{Summary and conclusions}

The paper has built on the premise that in Africa current population density and land use patterns (Figure $14 \mathrm{a}$ ) are closely related to climate (Figure $14 \mathrm{~b}$ ) and soil (Figure $14 \mathrm{c}$ ) conditions. It has supplied evidence to support the claim that African farmers cultivate sites where moisture supply conditions are fairly reliable and general soil suitability is moderate to high.

The soils currently in use are selected on account of their natural fertility, and hence of their suitability for low input agriculture but such soils also retain added nutrients rather well. It is therefore realistic to assume that yields can increase significantly if farmers apply the appropriate mix and dosage of fertilizer. Though the requirements strongly depend on local conditions, a three- to fourfold increase could lie within the realm of physical possibilities, but would entail a full transition from a technology that does not use external inputs to a high level-technology. 


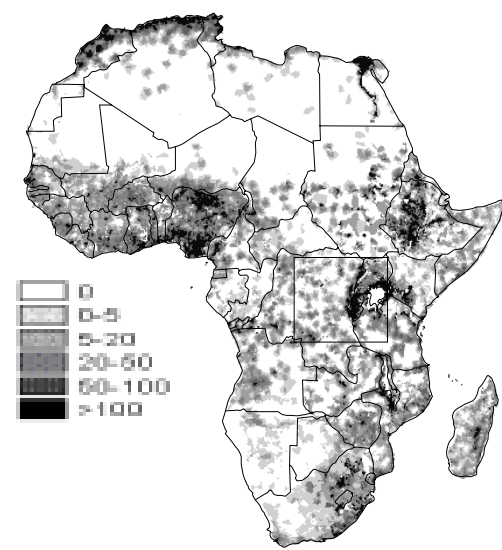

a. Population density

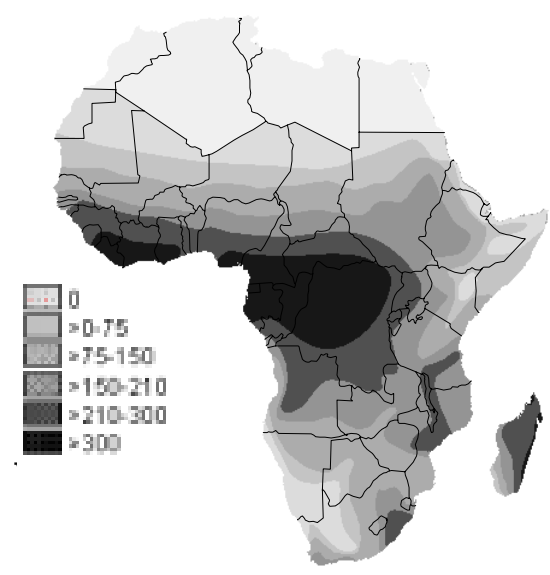

b. LGP zones

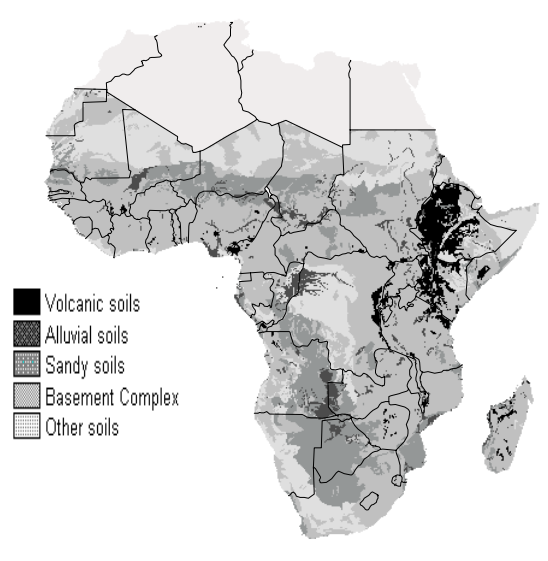

c. Soils

\section{Figure 14. Population, climate and soils}

In the 75-150 days LGP zone millet and short duration varieties of sorghum, maize and legumes will have to be selected in accordance with climatic conditions to ensure that the crop cycle is comfortably contained within the prevailing LGP. This will not only promote food security but also ensure that applied fertilizers are used more effectively. Where possible, the expansion of supplementary irrigation with e.g. low-lift pumps offers a further way to increase agricultural output.

The highest potentials for raising land productivity are located in the 150-210 days LGP zone because of the relative reliability of moisture supply and the in general favourable soil conditions. However, this zone also has a serious erosion hazard and although currently cultivated soils mostly are not very susceptible to erosion, they will become affected when land is used more intensively. This erosion hazard becomes more severe as new land is taken into use because it usually is more erodible.

Taking care of erosion hazard is also an important issue in the 210-300 days LGP zone. With respect to cereals the main emphasis has to be on maize, but otherwise large productivity gains are possible with root crops. The zone with LGP exceeding 300 days is not very suitable for intensification of land use. The areas at higher altitude have potentials and problems that are similar to the 150-210 days LGP zone and combine this with the additional advantage of being suitable for specialized (temperate) crops.

In virtually in all zones, except the one with LGP exceeding 300 days, fertilizers can be effective in raising crop yields. However, general fertilizer practices that have been successful elsewhere are not necessarily appropriate, as the requirements depend very much on local conditions of land ecology. 
The design of spatially explicit and appropriate fertilizer strategies is the most important challenge if agricultural production is to be increased.

It would have been easier to argue in this paper that Africa can improve its agricultural performance by a good mix of sound macro-economic policies and farmer participation in resource management at local level. Useful as such general recipes may be, they cannot bypass the realities of African land ecology, which imply that sites differ, that farmers do not avail of the information required for rapid growth, and that copying the Asian successes is not a viable proposition. Under low input conditions, agricultural performance largely depends on nutrient deficiencies at every location, which are often unknown and cannot be identified on the basis of prevailing yield and input levels. Promotion of foreign investment is not the answer either. While foreign investors might be interested in determining the specific micro-nutrients needs of the soils cultivated by their contractors, they have little incentive to engage in detailed studies at other sites, especially because these micro-nutrients are generally inexpensive and the quantities involved are, by definition, modest. Indeed, it seems that the issue has to be addressed through public initiatives, which could, for example, enable farmers to experiment on their fields with a limited set of alternative fertilizer mixes, as selected and supplied by local agricultural institutes. They would apply these mixes on separate plots to find out the most effective dosages. The agricultural institutes could provide the technical evaluation and follow up of the onfarm experiments, preferably with the necessary backup from international organizations and the corporate sector, in the spirit of the current Soil Fertility Initiative (Dudal, 1998; FAO, 1996; IFPRI, 1996). 


\section{References}

Alexandratos, N. ed. (1995) World agriculture: towards 2010, An FAO study. FAO, Rome and Wiley, Chichester.

Alexandratos, N. (1996) World food and agriculture: Outlook to 2010. Paper presented at the international seminar on agri-food policy making. University of Sienna, Italy, 7-9 November, 1996.

Aneke D.O. (1986) Coping with accelerated soil erosion in Nigeria. Journal of soil and water conservation. pp. 161-168.

APMEU (1987) The agronomic compendium, Volume III. Agricultural Project Monitoring and Evaluation Unit, Kaduna.

Barghouti S. and G. Le Moigne (1990) Irrigation in Sub-Saharan Africa. The development of public and private systems. World Bank technical paper number 123. World Bank, Washington.

Bederke, E and H.G. Wunderlich (1968) Atlas zur Geologie. Meyers grosser physischer Weltatlas, Band 2. Bibliographisches Institut, Mannheim.

Boli Baboule, Z. and E. Roose (1998) Degradation of a sandy Alfisol and restoration of its productivity under cotton/maize intensive cropping rotation in the wet savannah of Northern Cameroon. In: H.P. Blume, H. Eger, E. Fleischhauer, A. Hebel, C. Reij and K.G. Steiner (eds), Towards sustainable land use. Advances in geoecology 31. pp. 395-403. Catena Verlag, Reiskirchen, Germany.

Boyer, J. (1972) Soil Potassium. In: Soils of the humid tropics. National Academy of Sciences, Washington.

Boyer, J. (1978) Le Calcium et le Magnesium dans les sols des régions tropicales humides et subhumides. Initiations-Documentations Techniques 35. ORSTOM, Paris

Boyer, J. (1982) Les sols ferralitiques, Tome X: Facteurs de fertilité e utilisation des sols. Initiations-Documentations Techniques No. 52. ORSTOM, Paris.

Bumb, B.L. and C.A. Banaante (1996) Policies to promote environmentally sustainable fertilizer use and supply to 2020. IFPRI 2020 brief 40. IFPRI, Washington.

CDE Unpublished data. Centre for development and environment. University of Berne.

Cleaver, K.M. (1993) A strategy to develop agriculture in Sub-Saharan Africa and a focus for the World Bank. World Bank technical paper 203, Africa technical department series. World Bank, Washington.

Deckers, J. (1993) Soil fertility and environmental problems in different ecological zones of the developing countries in Sub-Saharan Africa. In: H. van Reuler and W.H. Prins (eds.), The role of plant nutrients for sustainable food crop production in Sub-Saharan Africa. VKR, Leidschendam, The Netherlands.

Deichman, U.1997. African Population Database Documentation. National Center for Geographic Information and Analysis University of California. Through GRID: http://grid2.cr.usgs.gov/data/.

Diemer G. and L.Vincent (1992) Irrigation in Africa: The failure of collective memory and collective understanding. Development Policy Review Vol. 19, pp. 131-154.

Dokuchaev, V.V. (1893) The Russian steppes and the study of soil in Russia, it's past and present (Translated by J.M. Crawford). Ministry of Crown Domains, St. Petersburg, Russia.

Dudal, R. (1998) Soil fertility initiative; an agro-ecological background. Internal paper, AGLS. FAO, Rome. 
Dudal, R. and R.N. Roy (1993) Integrated plant nutrition systems: report of an expert consultation. Rome, 13-15 December. FAO, Rome.

EagleInc (1990) Africa today: an atlas of reproducible pages, 1990 revised edition. World Eagle Inc., Wellesley

Elwell, H. and A.J. Norton (1988) No till tied ridging: a recommended sustained crop production system. Institute of Agricultural Engineering, Harare Zimbabwe.

English J., M. Tiffen and M. Mortimore (1994) Land Resource Management in Machakos District, Kenya, 1930-1990. World Bank Environment Paper No. 5. Environment Department. World Bank, Washington.

EROS (1998) GTOPO 30. Digital Elevation Model. EROS Data Center, Sioux Falls

Eswaran, H., F.H.Beinroth, J. Kimble and T. Cook (1992) Soil diversity in the tropics: Implications for agricultural development. In: R. Lal and P.A. Sanchez (eds.), Myths and science of soils in the tropics. SSSA Special Publication No. 29. SSSA, Madison.

FAO $(1978,1980,1981)$ Report on the agro-ecological zones project. Methodology and results for Africa, Southeast Asia and South and Central America. World soil resources report 48/1, 48/2, 48/3. FAO, Rome.

FAO (1979) Yield response to water. FAO irrigation and drainage paper 33. FAO, Rome.

FAO (1985) Guidelines: land evaluation for irrigated agriculture. FAO, Rome.

FAO (1991) World Soil Resources. An explanatory note on the FAO world soil resources map at 1: 25000000 scale. World soil resource reports 66, FAO, Rome.

FAO (1995) Irrigation in Africa in figures - L'irrigation en Afrique en chiffres, 1995 (E/F) Water reports 7. FAO, Rome.

FAO (1995) Digital Soil map of the World. Version 3.5. FAO, Rome.

FAO (1996) Plant nutrient management. FAO's contribution to the soil fertility initiative. Collection of background papers to the soil fertility initiative, Sub-Saharan Africa, published on internet.

FAO (1997a) Irrigation technology transfer in support of food security. Proceedings of a subregional workshop. Harare, Zimbabwe, 14-17 April 1997. FAO, Rome.

FAO (1997b) Negotiating a sustainable future for land. Structural and institutional guidelines for land resources management in the 21st century. FAO, Rome.

FAO (1998a) Guide to efficient plant nutrition management. FAO, Rome.

FAO (1998b) Spotlight rice crises looms in Asia. FAO/AG21/Magazine/spotlight /rice. Internet publication.

FAO/UNESCO (1973) The soil map of the world. FAO, Rome.

Fournier, F. (1962) Carte du danger d'érosion en Afrique au sud du Sahara. Communauté Economique Européene avec Commission de Coopération Technique en Afrique, Paris.

Greenland, D.J., A. Wild and D. Adams (1992) Organic matter dynamics in soils of the tropicsFrom myth to complex reality. In: R. Lal and P.A. Sanchez (eds.), Myths and science of soils in the tropics. SSSA Special Publication No. 29. SSSA, Madison.

Hassan, A. (1998) Improved traditional planting pits in the Tahoua department, Niger. In: C.Rey, I. Scoones and C. Toulmin (eds.), Sustaining the soil. Indigenous SWC in Africa. pp. 56-61. Earthscan, London.

Heisey, P.W. and W. Mwangi (1996) Fertilizer use and maize production in Sub-Saharan Africa. Economics Working Paper 96-01. CIMMYT, Mexico.

Hudson N. (1986) Soil Conservation. Batsford Ltd. London.

Hudson N. (1995) Soil Conservation. Iowa State University Press, Ames, Iowa. 
IFPRI (1996) IFPRI's contribution to the soil fertility initiative. Collection of background papers to the soil fertility initiative, Sub-Saharan Africa, published on internet.

Igbokwe, E.M. (1998) A SWC under threat. A visit to Maku, Nigeria. In: C.Rey, I. Scoones and C. Toulmin (eds.), Sustaining the soil. Indigenous SWC in Africa. pp. 219-227. Earthscan, London.

IOV (1995) Fertilizer aid. Evaluation of the Netherlands fertilizer aid 1975-1993 with special reference to Bangladesh, Mali and Zambia. IOV, Netherlands Development Cooperation, The Hague.

Jenny, H. (1980) The soil resource, origin and behaviour. Springer-Verlag, New York.

Jiyun, J. and Z. Guilan (1995) Plant nutrient management and sustainability of wheat based cropping systems in China. In: P. Gruhn, F. Goletti and R.N. Roy (eds.) Proceedings of the IFPRI/FAO workshop on plant nutrient management, food security, and sustainable agriculture: The future through 2020. IFPRI, Washington and FAO, Rome.

Kaihura, F.B.S., I.K. Kullaya, M. Kilasara, J.B. Aune, B.R. Singh and R. Lal (1998) Impact of soil erosion on soil productivity and crop yield in Tanzania. In: H.P. Blume, H. Eger, E. Fleischhauer, A. Hebel, C. Reij and K.G. Steiner (eds.), Towards sustainable land use. Advances in geoecology 31. pp. 375-382. Catena Verlag, Reiskirchen, Germany.

KARI (1994) Fertilizer use recommendations Vol. 1-22. Fertilizer use recommendation project. Kenya agricultural research institute, Nairobi.

Kassam, A.H., H. van Velthuizen, G.M. Higgins, A. Christoforides, R.L. Voortman and B. Spiers (1982) Assessment of land resources for rainfed crop production in Mozambique. Vol. 1-6. FAO/MOZ/75/011, Land and water use planning project. FAO, Rome.

Kassam, A.H., H.T. van Velthuizen, G.W. Fisher and M.M. Shah (1991) Agro-ecological land resources assessment for agricultural development planning, A case study of Kenya, Resources database and land productivity. FAO/IIASA, Rome/Laxenburg.

Kassogoué, M., M. Komota, J. Sagara and F. Schutgens (1998) A measure for every site. Traditional SWC techniques on the Dogon Plateau, Mali. In: C. Rey, I. Scoones and C. Toulmin (eds.), Sustaining the soil. Indigenous SWC in Africa. pp. 69-79. Earthscan, London.

Keyzer, M.A., J.W.A. Langeveld, M.D. Merbis, B.G.J.S. Sonneveld, W. Tims, W.C.M. van Veen, R.L. Voortman and C.F.A. van Wesenbeeck (1997) Perspective planning scenarios for Nigeria over the period 1996-2010. Main report of phase I. UNDP/UNDMMS/NPC and SOW-VU, Amsterdam.

King, L.C. (1951) South African scenery: a textbook of geomorphology. Oliver and Boyd, Edinburgh.

Klohn, W. and H. Wolter (1997) Perspectives of food security and water development. Proceedings of the International Workshop on Irrigation. DVWK, Bonn.

Kowal, J.M. and A.H. Kassam (1978) Agricultural ecology of savanna. A study of West Africa. Clarendon Press, Oxford.

Kowal, J.M. and A.H. Kassam (1977) Energy load and instantaneous intensity of rainstorms at Samaru, Northern Nigeria. In: D.J. Greenland and R.Lal (eds.), Soil Conservation and Management in the Humid Tropics. pp 57-70. Wiley, Chichester.

Lal, R. (1976) Soil erosion problems on an Alfisol in western Nigeria and their control. International Institute for Tropical Agriculture, Monograph no. 1. Ibadan, Nigeria, 208 p.

Lal, R. (1983) Soil erosion and its relation to productivity in tropical soils. In: S.A. El-Swaify, W.C. Moldenhauer and L.O. Andrew (eds.), Proceedings of the International Conference of Soil Erosion and Conservation, Hawaii: pp. 237-247. SCSA, Ankany, Iowa.

Lal, R. (1987) Tropical Ecology and Physical Edaphology. 732 p. Wiley, Chichester. 
Lal, R. (1990) Soil erosion in the tropics. Principles and Management. McGraw-Hill Publishing Cy. New York.

Lele, U. and A. Subramanian (1990) Sectoral strategy for irrigation development in Sub-Saharan Africa: Some lessons from experience. In: S. Barghouti and G. Le Moigne (eds.), Irrigation in Sub-Saharan Africa. The development of public and private systems. World Bank Technical Paper number 123. World Bank, Washington.

Lind, E.M. and M.E.S. Morrison (1974) East African vegetation. Longman, London.

Loxton-Huntings (1977) Vegetation and land use map. Federal Department of Forestry, Ministry of Agriculture and Rural Development. Hunting's Technical Services Ltd., Borehamwood.

Mason, R. (1978) Petrology of the metamorphic rocks. Textbook of Petrology volume III. Allan and Unwin, London.

Mbagwu, J.S.C., R.Lal and T.W. Scott. (1984) Effects of desurfacing of Alfisols and Ultisols in southern Nigeria: I. Crop performance. Soil Sci. Soc. Am. J. 48: 828-833.

Mbegu, A.C. (1998) Making the most of compost: a look at wafipa mounds in Tanzania. In: C. Rey, I. Scoones and C. Toulmin (eds.), Sustaining the soil. Indigenous SWC in Africa. pp. 134-138. Earthscan, London.

Millar D. and R. Ayariga and B. Anamoh (1998) "Grandfathers ways of doing": gender relations and the yabaitgo system in Upper East Region, Ghana. In: C. Rey, I. Scoones and C. Toulmin (eds.), Sustaining the soil. Indigenous SWC in Africa. pp. 117-125. Earthscan, London.

MinCo (1980) Mémento de l'agronome. Collection techniques rurales en Afrique. Ministère de la Coopération, Paris.

Mohammed, Y.A. (1998) Drought and the need to change. The expansion of water harvesting in Central Darfur, Sudan. In: C. Rey, I. Scoones and C. Toulmin (eds.), Sustaining the soil. Indigenous SWC in Africa. pp. 35-43. Earthscan, London.

Mokwunye, A.U. and L.L. Hammond (1992) Myths and science of fertilizer use in the tropics. In: Lal, R and P.A. Sanchez (eds.), Myths and science of soils in the tropics. SSSA Special Publication No. 29. SSSA, Madison.

Mokwunye, A.U., A de Jager and E.M.A. Smaling (1996) Restoring and maintaining the productivity of West-African Soils: Key to sustainable development. Miscellaneous Fertilizer studies No. 14. IFDC-Africa.

Morgan R.P.C. (1995) Soil erosion and conservation. Longman Group Ltd., Harlow, Essex.

Moyo, A. (1998) The effect of soil erosion on soil productivity as influenced by tillage: with special reference to clay and organic matter losses. In: H.P. Blume, H. Eger, E. Fleischhauer, A. Hebel, C. Reij, K.G. Steiner (eds.), Towards sustainable land use. Advances in geoecology 31. pp. 363-368. Catena Verlag, Reiskirchen, Germany.

Mullenders, W. (1954) La végétation de Kaniama (entre Lubishi-Lubilash, Congo, belge). Publications INEAC, Serie Scientifique, 61, p. 1-499.

Nill D., U. Schwertmann, U. Sabel Koschella, M. Bernhard and J. Breuer (1996) Soil erosion by water in Africa. Principles, prediction and protection. GTZ verlag, GTZ, Rossdorf, Germany.

Nockolds, S.R., R.W.O'B. Knox and G.A. Chinner (1978) Petrology for students. Cambridge University Press, Cambridge.

Ojeniyi, S.O. and G.O. Kayode (1993) Response of maize to copper and sulfur in tropical regions. Journal of agricultural science, 120: 295-299.

Oldeman L.R., R.T.A. Hakkeling and W.G. Sombroek (1991) World map of the status of human induced soil degradation. ISRIC/UNEP, Wageningen. 
Ouedragao, M. and V. Kaboré (1998) The Zai: a traditional technique for the rehabilitation of degraded land in the Yatenga, Burkina Fasso. In: C. Rey, I. Scoones and C. Toulmin (eds.), Sustaining the soil. Indigenous SWC in Africa. pp. 80-84. Earthscan, London.

Oyedele, D.J. and P.O. Aina (1998) A study of soil factors in relation to erosion and yield of maize on a Nigerian soil. Soil and Tillage Research. 48. pp. 115-125.

Philip, G. (1981) Philips' concise atlas of the world. George Philip, London.

Pieri, C.J.M.G. (1992) Fertility of soils; A future for farming in the West-African Savannah. Springer-Verlag, Berlin.

Pimentel, D. (1995) Environmental and economic costs of soil conservation and conservation benefits. Science, Vol. 267, pp. 1117-1123.

Quiñones, M.A., N.E. Borlaug and C.R. Dowswell (1997) A fertilizer-based green revolution for Africa. In: R.J. Buresh, P.A. Sanchez and F. Calhoun (eds.), Replenishing soil fertility in Africa. SSSA special publication No. 51. SSSA, Madison.

Reuler, H. van, and W.H. Prins (1993) Plant nutrients and food production. In: H. van Reuler and W.H. Prins (eds.), The role of plant nutrients for sustainable food crop production in SubSaharan Africa. VKR, Leidschendam, The Netherlands.

Rey, C. I. Scoones and C. Toulmin (1998) Sustaining the soil: indigenous soil and water conservation in Africa. In: C. Rey, I. Scoones and C. Toulmin (eds.), Sustaining the soil. Indigenous SWC in Africa. pp. 1-27. Earthscan, London.

Rodel, M.G.W. and J.D.H. Hopley (1973) Investigations into systems of farming suitable for tribal trust land. Rhodesia Agricultural journal, Vol. 70, No. 1.

Roose, E. (1977) Application of the Universal Soil Loss Equation in West Africa. In: D.J. Greenland and R. Lal (eds.), Soil conservation and management in the humid tropics. Wiley, Chichester.

Roose, E. (1997) Agroforestry, water and soil fertility management to fight erosion in tropical mountains of Rwanda. Soil Technology 11: pp. 109-119.

Roose, E. (1998) Méthodes traditionelles de gestion de l'eau et des sols en Afrique occidentale soudano-sahélliene; définitions, fonctionnements, limites et améliorations possibles. Bulletin Reseau Erosion, vol 10.

Ruthenberg, H. and H.E. Jahnke (1985) Innovation policy for small farmers in the tropics. The economics of technical innovations for agricultural development. Clarendon Press, Oxford.

Sabel-Koschella U. (1988) Field studies on soil erosion in the southern Guinea savanna of Western Nigeria. Ph.D. thesis, Lehrstuhl für Bodenkunde. Technische Universität, München, Germany:180 pp.

Sammani, M.O. and S.M.A. Dablouh (1998) Making the most of local knowledge. Water harvesting in the Red Sea hills of Northern Sudan. In: C. Rey, I. Scoones and C. Toulmin (eds.), Sustaining the soil. Indigenous SWC in Africa. pp. pp. 28-34. Earthscan, London.

Sanchez, P.A. and T.J. Logan (1992) Myths and science about chemistry and fertility of soils in the tropics. In: R. Lal and P.A. Sanchez (eds.), Myths and science of soils in the tropics. SSSA Special Publication No. 29. SSSA, Madison.

Sanchez, P.A., K.D. Sheperd, M.J. Soule, F.M. Place, R.J. Buresh, A.N. Izac, A.U. Mokwunye, F.R. Kwesiga, C.G. Ndirito and P.L. Woomer (1997) Soil fertility replenishment in Africa: An investment in natural resource capital. In: R.J. Buresh, P.A. Sanchez and F. Calhoun (eds.), Replenishing soil fertility in Africa. SSSA special publication No. 51. SSSA, Madison. 
Showers, K.B. and G. Malahleha (1990) Pilot study for the development of methodology to be used for an historical environmental impact assessment of colonial soil conservation schemes. Paper presented at the Workshop on Conservation in Africa: Indigenous Knowledge and Conservation Strategies, 2-7 December, Harare.

Slingerland, M. and Mouga Masdewel (1998) Mulching on the Central Plateau of Burkina Faso: widespread and well adapted to farmers' means. In: C. Rey, I. Scoones and C. Toulmin (eds.), Sustaining the soil. Indigenous SWC in Africa. pp. 85-89. Earthscan, London.

Smaling, E.M.A. (1993) An agro-ecological framework for integrated nutrient management, with special reference to Kenya. Thesis, LUW, Wageningen.

Smaling, E.M.A., S.M. Nandwa, H. Prestele, R. Roetter and F.N. Muchena (1992) Yield response of maize to fertilizers and manure under different agro-ecological conditions in Kenya. Agriculture, Ecosystems and Environment 41(1992): 241-252.

Snijders, F.L. (1985) Land use inventory of Mozambique. Série Terra e Água, Communicação No. 43. INIA, Maputo.

Sombroek, W.G. and I.S. Zonneveld (1971) Ancient dune fields and fluviatile deposits in the RimaSokoto river basin (N-W Nigeria). Soil survey papers No. 5. Netherlands soil survey institute, Wageningen.

Spiers, B. (1995a) Soil as a determinant in the vegetation of savanna. English draft for Enciclopèdia Catalana; Biosfera, els humans en els àmbito ecologics del món; 3 Sabanes. Fundació Enciclopèdia Catalana, Barcelona.

Spiers, B. (1995b) The soils of Asian savanna's. English draft for Enciclopèdia Catalana; Biosfera, els humans en els àmbito ecologics del món; 3 Sabanes. Fundació Enciclopèdia Catalana, Barcelona.

Spiess, E. (1997) Schweizer Weltatlas. EDK, Bern.

Stiles G. (1996) Demand-side Management, Conservation, and Efficiency in the Use of Africa's Water Resources. In: E. Rached, E. Rathgeber, and D. B. Brooks (eds.), Water Management in Africa and the Middle East, Challenges and Opportunities. IDRC, Canada.

Stoorvogel, J.J., E.M.A. Smaling and B.H. Jansen (1993) Calculating soil nutrient balances in Africa at different scales. I. Supra -national scale. Fertilizer research 35: 227-235.

Tandon, H.L.S. (1995) Use of external inputs and the state of efficiency of plant nutrient supplies in irrigated cropping systems in Uttar Pradesh, India. In: P. Gruhn, F. Goletti and R.N. Roy (eds.), Proceedings of the IFPRI/FAO workshop on plant nutrient management, Food security, and sustainable agriculture: The future through 2020. IFPRI, Washington and FAO, Rome.

Tchawa, P. (1998) Evaluation of traditional techniques of soil conservation in the Bamileke region, West Cameroon. In: C. Rey, I. Scoones and C. Toulmin (eds.), Sustaining the soil. Indigenous SWC in Africa. pp. 228-234. Earthscan, London.

Tiffen, M., M. Mortimore and F. Guchinki (1994) More people, less Erosion: Environmental Recovery in Kenya. John wiley, Chichester.

Trapnell C.G. and I. Langdale-Brown (1972) Natural Vegetation. In: Morgan, W.T.W. (ed.), East Africa: its peoples and resources. Oxford University Press, London.

Troll, C. (1950) Die geografischen Landschaft und ihre Erforschung. Studium Generale 3. Springer-Verlag, Heidelberg.

Vink, A.P.A. (1975) Land use in advancing agriculture. Advanced series in agricultural sciences 1. Springer-Verlag, Heidelberg. 
Voortman, R.L.(1988) Agricultural crisis in Africa; Land ecology, farming systems, land use planning and the role of science and technical assistance in development planning. ISS research paper. ISS, The Hague.

Voortman, R.L. (1998) Recent historical climate change and its effect on land use in the eastern part of West Africa. Physics and Chemistry of the Earth, Vol. 23, No. 4 pp. 385-391.

Voortman, R.L. and B. Spiers (1986) Angonia, Landscape ecological survey and land evaluation for rural development planning, Angonia district, Tete province. INIA, Série Terra e Água, Comunicação No. 33. INIA, Maputo and FAO, Rome.

Walter, H. (1984) The vegetation of the earth and ecological systems of the geo-biosphere. SpringerVerlag, Berlin.

Wambeke, A. van (1974) Management properties of Ferralsols. FAO soils bulletin 23. FAO, Rome.

Whitlow, J.R. (1988) Soil conservation history in Zimbabwe. Journal of Soil and Water Conservation. Vol. 43, no 4, pp. 299-303.

Wielemaker, W.G. and H.W. Boxem eds. (1982) Soils of the Kisii area, Kenya. Pudoc, Wageningen.

Wild, H. and A. Fernandes eds. (1967) Flora Zambesiaca supplement: Vegetation map of the Flora Zambesiaca area. Collins, Salisbury.

Woodhouse, P.J. and C.J. Rendle (1983) Programa de ensaios de adubação. Relatório trienal 19791982. Série Terra e Água, Comunicações No. 23. INIA, Maputo.

World Bank (1989) Sub-Saharan Africa: From crisis to sustainable growth; A long-term perspective study. World Bank, Washington.

World Bank (1996a) Towards environmentally sustainable development in Sub-Saharan Africa; A World Bank agenda. World Bank, Washington

World Bank (1996b) Taking action to reduce Poverty in Sub-Saharan Africa. An Overview. World Bank, Washington.

Zonneveld, I.S. (1995) Land Ecology. An introduction to landscape ecology as a base for land evaluation, land management and conservation. SPB Academic publishing, Amsterdam. 